\title{
Rediscovering Date Palm by-products: an Opportunity for Sustainable Development
}

\author{
H. El-Mously \\ Dept. of Design and Production, Ain Shams University, Egypt \\ hamed.elmously@gmail.com
}

Keywords: date palm, palm midrib, endogenous development, rediscovery of local resources, palm by-products, bioeconomy, date waste, lignocellulosic by-products

\begin{abstract}
The date palm was the pivot of cultural, social and economic life for long centuries in rural areas in the Arab region. The basic needs of millions of people in rural areas were being satisfied relying on the by-products of date palms. With the drastic change of the style of life most of these byproducts became redundant leading to the neglect of pruning of date palms, and thus becoming a direct cause of fire accidents and infestation by dangerous insects. This situation represents a real challenge to those concerned with development. How to compose a new vision to palm by-products transcending the traditional forms of utilization of these by-products being treated as waste? The path of rediscovery of these by-products is paramount. How to develop new forms of utilization of palm by-products to satisfy modern demands on the local, national and international levels? An approach has been suggested for the industrial utilization of date palm by-products.

The research conducted at the premises of the Faculty of Engineering, Ain Shams University has proven that the date palm midribs enjoy mechanical properties similar to those for imported wood species. It was also proven that the date palm midrib can be used as a core layer for the manufacture of blockboards competing with those manufactured from wood. Lumber-like blocks have been successfully made from palm midribs. The palm midribs were successfully used for the production of Mashrabiah (Arabesque) products as a substitute for beech wood. Particleboards and MDF boards satisfying the international standards have been also manufactured from palm midribs. Poultry and livestock feed, as well as compost have been produced using the date palm midribs. Space trusses and claddings have been successfully made from palm midribs. New machines have been successfully designed and manufactured for the conversion of palm midribs into strips of regular cross-section. There are wide future prospects for the use of date palm by-products us a substitute for wood, for paper manufacture and for the reinforcement of polymers. Within the framework of bioeconomy there are high potentialities for the use of the date waste, as well as the ligne-cellulosic by-products in a wide spectrum of bioindustries. To guarantee the continuation of endeavors to support the use of palm by-products on the international level it is necessary to establish The International Association For Palm ByProducts as a forum for all parties interested and involved in the use of palm by-products.
\end{abstract}

\section{Introduction}

The palm plantations were the pivot of cultural, social, and economic life for long centuries in rural areas in the South: in Latin America, Africa, and Asia. The basic needs of millions of people in rural areas were being satisfied relying on the by-products of palms (PBP). The way of life in these vast areas was woven using these available indigenous sustainable secondary products of palms. Via this process very rich technical heritage blossomed, being mainly the 
property of the poor in the local communities in rural areas. The shift from the prevailing subsistence economy to the capitalist mode of production and the dominance of the cash crop ideology, together with the propagation of the Western life style has led to the negligence of PBP and the freezing of the associated technical heritage. Thus, the rural populations in many countries in the South turned from producers and active participants in development of their local communities to mere consumers of whatever could be purchased from cities or abroad.

This situation represents a real challenge to those concerned with development. How to compose a new vision to PBP transcending the traditional forms of utilization of PBP and imagining new modern avenues of utilization of these renewable almost priceless and voluminous materials being, presently regarded as waste?

The path of rediscovery of PBP is paramount in this context. How to develop new forms of utilization of PBP to satisfy modern demands on the local, national and international levels? Adopting a participatory approach this trend of thought may provoke waves of innovation: beginning from the rural areas and reaching urban areas. The economic utilization of PBP will provide labor opportunities on the local level, attract the youth back to village as innovators and entrepreneurs and transform the village from pure reliance on the agricultural activity, subject to the fluctuations of prices of the agricultural products, to a wide sphere of economic activity including beside agriculture, industry and trade. Thus, the economic utilization of PBP will return vitality to local communities, where the palm plantations exit and provide appropriate conditions for sustainable development.

\section{The date palm in the cultural history of the Arab region}

The local materials are nothing but the material milieu, through which cultures were able to express themselves. Proceeding from the historical perspective, the different cultures of the world were born and developed in company with different materials. Who could deny the relation between the ancient Egyptian culture and papyrus, lotus, lime stone and granite, nor between the Asian cultures and bamboo, rattan and rice? It is extremely important to capture the relation between culture and local materials as an important asset for development. The linking between development and local materials means that you are building on the existing culture of interaction with these materials, i.e., you do not begin development from a zero datum, but with what people - members of each local community - have at hands (the local materials), as well as in minds (psychological familiarity with these materials, as well as technical heritage, associated with their production, manufacture and use in the different walks of life). In this concern the date palm (Phoenix dactylifera L.), represents an eloquent example. It is an authentic element of the region's flora, which accompanied our historical march for thousands of years. It is our duty now as researchers and intelligentsia to rediscover the date palm as a pivot for our life at present, as well as for the future generations.

It may be difficult to record the first emergence in history of the date palm, but it was well known 4000 years BC, where it was used to build the moon temple near to Ore, south of Iraq [50]. The second proof of the ancient presence of the date palm comes from the Nile valley, where the date palm was taken as the symbol of the year and the palm midrib as a symbol of the month in the hieroglyphic Egyptian language. But the cultivation of the date palm in Egypt was 2000 - 3000 years later than in Iraq [50]. The date palm was one of the pivots of economic and, hence, social and cultural life in this region from ancient times. In ancient Egypt the heads of pillars in temples were made resembling the growing top of the date palm. The date palm appeared frequently on walls of temples in different contexts revealing its significance in life in Egypt. According to Nubian (south Egypt) traditions, when a child is born, they plant a date 
palm for him. When he has matured, the date palm will have grown to a number of palms, providing a basis for his future economic life. In Upper Egypt each village has evolved beside its life supporting palm plantations. The date palm is well adapted to our environment. It is grown well in the Nile Valley, where it gives gentle shade against the sun and protection from the wind to crops growing below it. It tolerates the harsh climate of the Sahara, making possible the life of Bedouins; it even tolerates high levels of salinity, growing along the seashore in Egypt. It needs much less water and service and is less subject to diseases and parasites than other trees.

Date, the primary product of the palm is rich in protein, vitamins, and mineral salts. That is why it represents an essential element of diet for the cultivator himself and his animals (the lowgrade date with kernel). All secondary products of the palm result from annual pruning (Fig. 1) and have essential uses for the cultivator. Thus, no waste results from the growing of palms. The date palm's midribs of grown palms after being woven in a mat using coir ropes are used in roofing ${ }^{(1)}$. Crates for the transportation of vegetables and fruits are also made from the palm midrib, as well as furniture items, manual fans, doors of gardens and coops for chickens and rabbits.

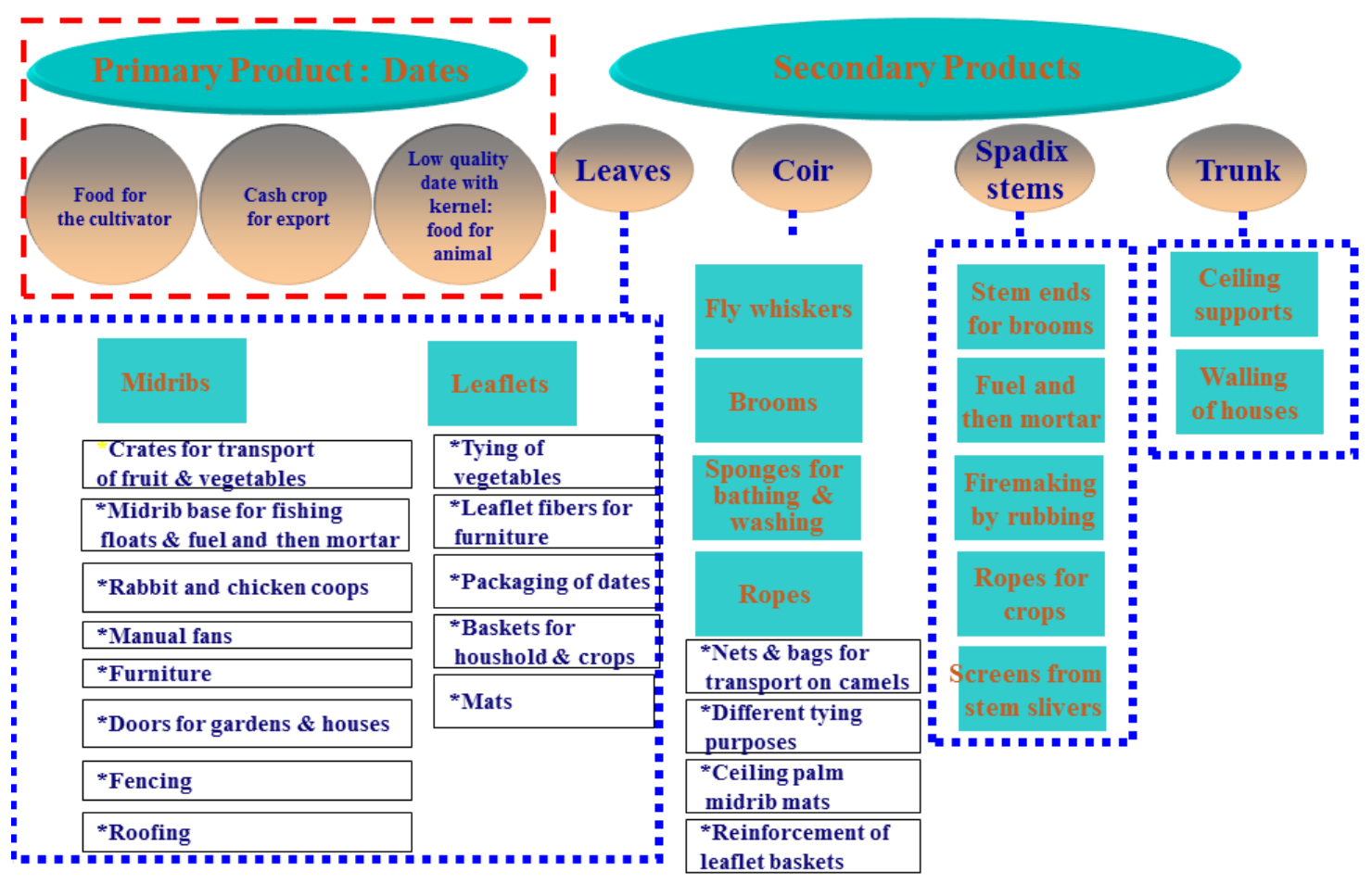

Fig. 1: The date palm: a pivot for the ways of life in our traditional communities [27].

Midribs of young palms are used in fencing gardens. The midrib base is used as floats for fishing nets or for fuel in rural ovens: the ashes being used afterwards in mortar. The leaflets are used after being woven, in mat making, as well as in a very wide variety of baskets for use in the cultivator's household, as well as for transportation of various agricultural crops and packing of

1 - This was my first acquaintance with palm midribs. Roofs in El-Arishi traditional houses, made of midribs, lasting for centuries, were my first natural proof of their durability and good mechanical properties. 
dates. They are also used for the manufacture of screens for households and as ropes for typing up vegetables. The leaflet fibers are used in the manufacture of carina used for stuffing of upholstered furniture. The coir is being used for making washing and bathing sponges, as well as for the manufacture of ropes for different uses. From coir, rope nets, and bags for the transportation of agricultural crops on camels are being made. Household brooms and fly whiskers are also made from coir. The spadix stem is crushed to obtain very strong fibers for tying up agricultural crops. The spadix stem ends with fruit stalks are used as brooms in streets. Spadix stems of certain palm species were even used for fire making by rubbing. They were also used as coat hangers, and after being sliced into strips, were used for making screens for household use. The palm trunk is being used, after cutting it into halves or quarters, as beams for ceilings or walling in rural and desert regions. Thus, the date palm in our traditions (Fig. 1) represented an eloquent example of integrated sustainable use of renewable material resources.

\section{How we got in touch with the palm midrib and why we focused our research on the palm midrib}

We - as city dwellers - are accustomed to look with scorn to the agricultural materials coming from the village. During the years of engineering education we learned to respect the industrial materials, such as steel, cast iron and aluminum. Thus, we developed negative attitudes towards the materials coming from the village, such as palm midribs. During a scientific journey we made to North Sinai in November, 1979 I [1] saw - for my first time - the palm midribs in the roofs (Fig. 2) of the traditional houses in El-Arish. I was astonished to learn that such roofs remain in a good state for hundreds of years. This meant for me a natural experiment emphasizing the good mechanical properties of the palm midrib.

Our extensive field studies, conducted in several governorates in Egypt, showed that there are very rich potentialities for development, which need to be activated. A wide spectrum of natural material resources is available everywhere depending on the geology, climate and history of each locality. These resources are not by themselves of value, isolated from the community. They acquire their real value by virtue of the wealth of experience and spirit of endogenous creativity of each local community. We perceive of the local community as a socio-cultural-ecological subsystem, i.e., the local group in its relation with the surrounding environment. Thus, endogenous development could begin in each local community with what people have more of and know better about[50]. Table (1) illustrates that the date palm exists almost in all Egypt governorates. Secondly we got a very strong evidence that the drastic change in the way of life in Egypt has made palm midribs redundant: people stopped using it in ceiling, fencing, doors and even to a large extent in crates. Thus, palm midribs in many governorates turned to be "waste": a burden and source of pollution to the environment and sometimes a cause of fire in the palm gardens. Since the price of date in the palm garden is very low, we found that this situation may threaten the economic feasibility of cultivation of the date palm as a whole, which may deprive people, particularly the poor from an essential element of their diet. Besides, I was so strongly convinced with the idea of endogenous development and felt that the palm midribs - extensively available in Egypt and the Arab world - may serve as the material milieu for the application of the idea of endogenous development in local communities possessing date palms. 


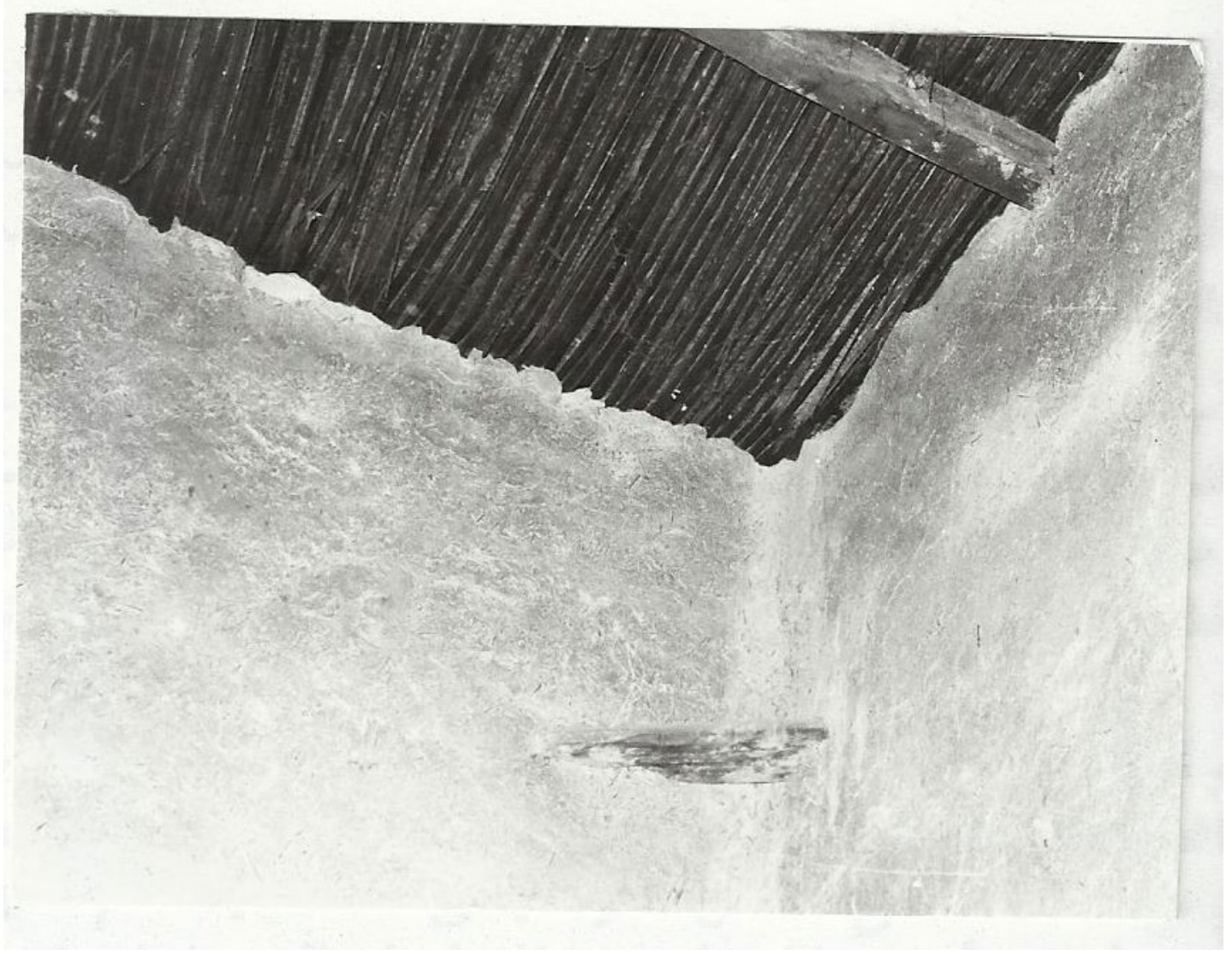

Fig. 2: The ceiling of a traditional Arishi house, made from palm midribs [2] 
Table 1: Estimation of the production of date in Egypt, 2015 [5].

\begin{tabular}{|c|c|c|c|c|}
\hline Governates & Area & $\begin{array}{c}\text { fruitful } \\
\text { palm } \\
\text { (palm) }\end{array}$ & $\begin{array}{c}\text { Productivity } \\
\text { (Kg palm) }\end{array}$ & $\begin{array}{c}\text { Production } \\
\text { (ton) }\end{array}$ \\
\hline Alexandria & 436 & 82563 & 83.706 & 6911 \\
\hline Beheira & 14327 & 1371794 & 168.436 & 231060 \\
\hline Garbiya & 315 & 48368 & 103.560 & 5009 \\
\hline Kafr El Sheikh & 5159 & 343427 & 128.062 & 43980 \\
\hline Dekhalia & 674 & 216716 & 110.010 & 32841 \\
\hline Damiatta & 15 & 866216 & 99.166 & 85899 \\
\hline Sharkia & 260 & 1211196 & 171.536 & 207764 \\
\hline Ismailia & 1327 & 670532 & 131.809 & 88382 \\
\hline port said & - & 11195 & 84.413 & 945 \\
\hline El suez & 456 & 93879 & 94.590 & 8880 \\
\hline Monofia & 75 & 163339 & 100.656 & 16441 \\
\hline Qalyubia & 547 & 203469 & 125.729 & 25582 \\
\hline Cairo & 810 & 37586 & 53.424 & 2008 \\
\hline Lower Egypt & 24392 & 5320280 & 140.350 & 746702 \\
\hline (Total) & 21089 & 1813322 & 130.798 & 237178 \\
\hline Giza & 61 & 320783 & 92.324 & 29616 \\
\hline Beni Suef & 1158 & 643074 & 133.832 & 86046 \\
\hline Faiyum & 586 & 337608 & 110.000 & 37137 \\
\hline Minya & 22894 & 3114787 & 125.208 & 389995 \\
\hline Middle Egypt \\
(Total) & 400 & 462501 & 95.431 & 44137 \\
\hline Asyut & 799 & 414071 & 93.291 & 38713 \\
\hline Sohag & 1039 & 361346 & 61.368 & 22175 \\
\hline Qena & 552 & 192360 & 70.254 & 13514 \\
\hline Luxor & 24840 & 2477458 & 90.840 & 225054 \\
\hline Aswan & 27630 & 3908663 & 87.906 & 343593 \\
\hline $\begin{array}{c}\text { Upper Egypt } \\
\text { (Total) }\end{array}$ & 74916 & 12343730 & 119.922 & 1480290 \\
\hline $\begin{array}{c}\text { Inside Valley } \\
\text { (Total) }\end{array}$ & 18482 & 1262475 & 81.681 & 103120 \\
\hline New Valley & 7207 & 330674 & 90.001 & 29761 \\
\hline Matruh & 134 & 39528 & 42.856 & 1694 \\
\hline Red Sea & & & \\
\hline & & & & \\
\hline
\end{tabular}




\begin{tabular}{|c|c|c|c|c|}
\hline North Sinai & 9076 & 320650 & 53.429 & 17132 \\
\hline South Sinai & - & 91304 & 39.998 & 3652 \\
\hline Nubariya & 5795 & 567970 & 86.744 & 49268 \\
\hline Outside Valley (Total) & 40694 & 2612601 & 78.323 & 204627 \\
\hline Total & 115610 & 14956331 & 112.656 & 1684917 \\
\hline
\end{tabular}

\section{Rediscovery of renewable materials: the palm midrib as an example}

I think that we researchers should not take the path of imitation of Western scholars in selection of our subjects of scientific interest. Our natural materials are the material milieu, via which our scientific and technological capabilities could mature. Many of these materials, such as palm midrib, found so many genuine forms of utilization in our traditional ways of life [27]. The study of these material's traditional uses could be very useful in order to learn more about their physical and mechanical properties. However, these materials are often produced and/or consumed only in certain social strata in villages. For example, the palm by-products in Southern countries are usually associated with the poor in rural areas, whether as producers, manufacturers or consumers. With the change of the way of life the demand on products from these materials decreases. This leads to the neglect of these materials and the collapse of the primary activity producing them, leading in turn to the marginalization of rural areas, poverty and the collapse of the local community. What is needed is a new perception of local materials in a context much wider than the traditional context. This means:-

(a) designing products or services for the satisfaction of new contemporary needs on the level of the local community in villages;

(b) or widening the circle of consumption to include higher (medium and upper) classes in cities locally or abroad. This includes the design of new products to satisfy the needs of new markets;

(c) introducing more advanced modern technologies with the objective of improving product quality, increasing productivity, introducing new product characteristics or functions, and developing new technologies for totally new lines of products.

Thus, what is called the rediscovery of renewable materials means: imagining, thinking, designing, carrying out research and producing new product prototypes, conducting market research, etc. in a very interactive fashion as shown in Fig. 3, with the objective of developing new uses of the local materials. Returning to the local community level this means the creation of a new pattern of sustainability and the transition from subsistence to market economy and from the traditional to an authentic form of modernity for the local community.

Fig. 4 illustrates the different alternatives of rediscovering the palm midrib and the associated product versions. 


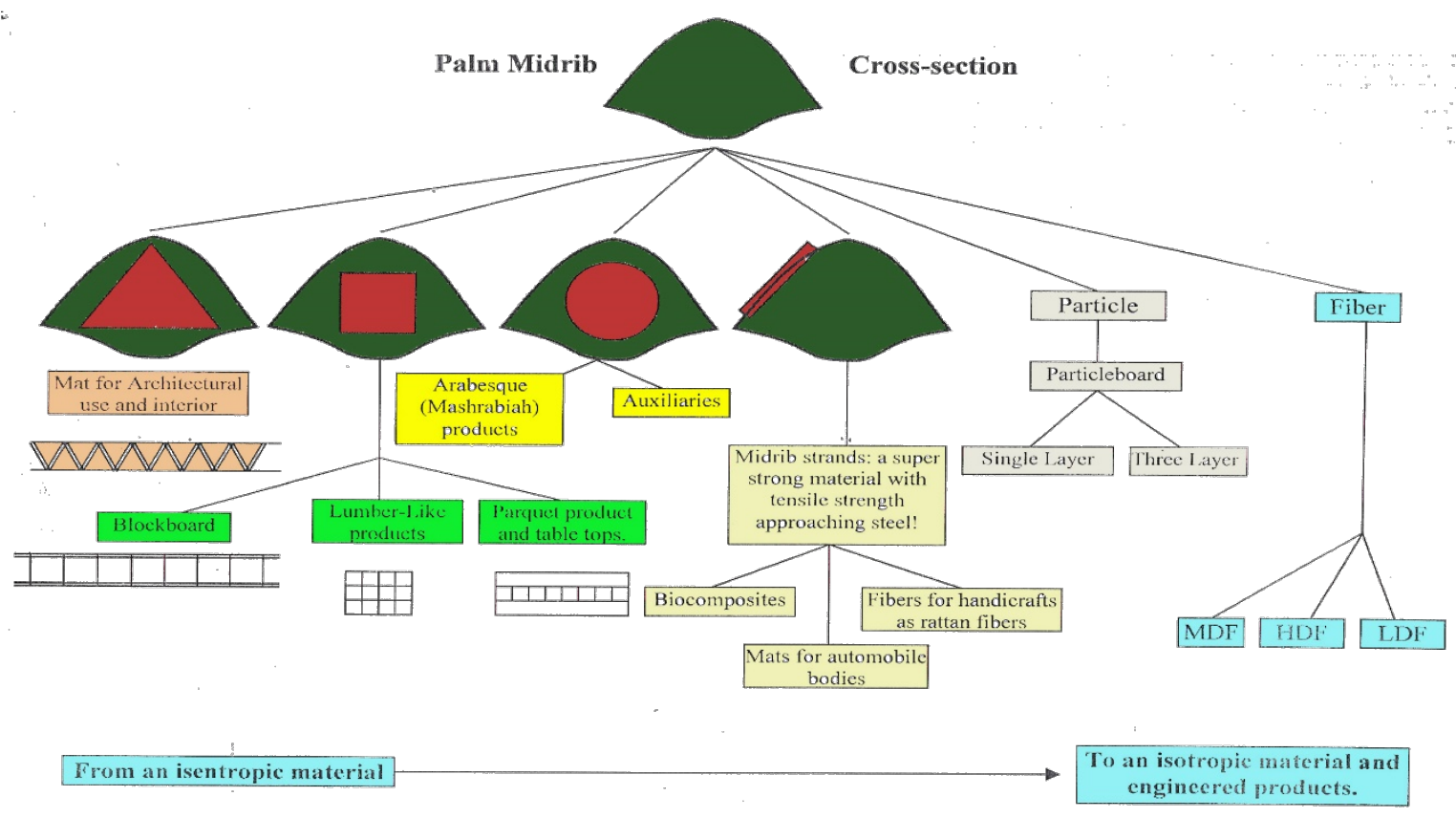

Fig. 3: A synergetic dialogue has been lunched between the designers and EGYCOM technical team leading to the innovation of new products from palm midribs and leaflets.

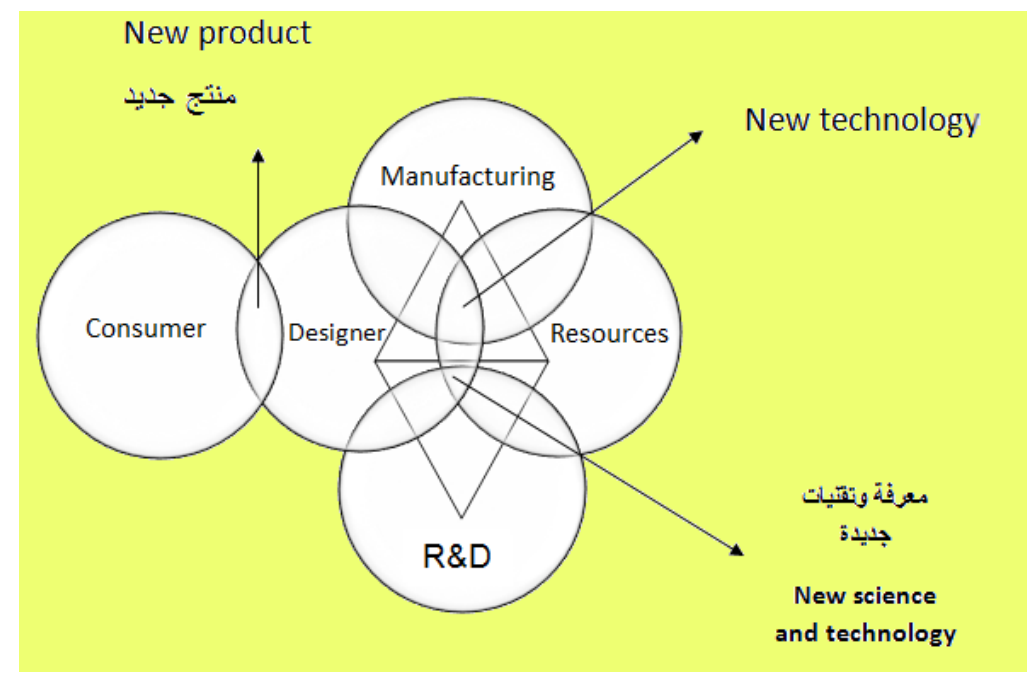

Fig. 4: Different alternatives of rediscovering the palm midrib and the associated products vision.

\section{Interfaces of innovation}

We could discern two interfaces of innovation.

1. The first interface lies between our perception of the physical and mechanical properties of the date palm by-products and our perception of the performance criteria of different products or services. The outcome of this interface is an idea of a new product or service.

2. The second interface of innovation lies between the idea of a certain product or service and the socio-economic and cultural aspects of the local society, where the product or service is to be produced. The outcome of this interface is an appropriate technology that the local 
community could assimilate, digest, and thus becomes stronger, so that it could afterwards develop it independently.

\section{The approach we followed for the industrial utilization of the date palm by-products}

The suggested approach proceeds from the principle of rediscovery of our local materials. This means that we should direct our forces of imagination and thinking to find new avenues for the utilization of these materials within a vision for development and modernization we set by ourselves. Therefore, we do not resort to replicate the ways of life and patterns of production our forefathers have had, nor to the blind imitation of the Western pattern of development and modernization. This approach leads us to an intermediate situation, whereby we could make maximum use of our development potentialities and comparative and competitive advantages and utilize the Western scientific and technological achievements, while giving due attention to the specificity of our situation and cultural vision. In addition, the principle of rediscovery of our local materials means that we put each generation before the challenge of innovation to develop its own edition of use of local materials, which will unleash its potential energies and creative power and push it forward to participate actively in the development of society. The suggested approach includes the following steps.

1. The conduction of tests to determine the physical and mechanical properties of the palm byproducts according to the latest international standards. This is thought to give a new identity to these materials and put it in comparison with the similar materials in the international market.

2. Development of new products from the palm materials proceeding from the knowledge about their physical and mechanical properties, and chemical composition, as well as from the specificity of local, national and international needs.

3. Design of the manufacturing processes and machines for the aforementioned products taking into consideration the features of the socio-cultural context, where the industrial activity will be located. The image of industrial establishment may not take the image of the orthodox factory. The village with its palm gardens and houses with inner courts may be an appropriate context for industrialization. It is a new mode of engineering trying to initiate a dialogue with that culturally specific context, so that the new scientific and technological inputs become harmonious with that context, which could be thus able to digest and assimilate them and get stronger and more developed.

4. Determination of the appropriate manufacturing process parameters. This necessitates the conduction of applied research to attain definite required results: the determination of the values of these parameters. This we call development and research (D \& R and not R \& D). Firstly, efforts are devoted to find a new avenue or use of the resource (e.g. product prototypes). When we succeed in these exploratory experiments in manufacturing a product satisfying the needed consumption criteria and get clear economic indices of success of marketing of the product via market research, we go back to the manufacturing process and conduct research to find the optimum conditions of manufacturing the product: both technically and economically. This approach is much more appropriate in Southern countries having limited funds, allocated to research.

5. Design, manufacturing and testing of the prototypes of equipment needed for manufacture and their modification if necessary, to cope with the needed performance requirements. 
6. The establishment of an experimental pilot unit for the new products putting the new industrial potentiality under test: technologically and economically. This is the first step to convince the entrepreneurs to invest in this new field of industrial activity, the market specialists to open new markets for these products, as well as the consumers to accept the new products, made from the palm by-products.

7. The conduction of technical and economic feasibility studies to establish industrial projects relying on the palm by-products. These studies should give the detailed technical information (specifications of equipment and operations sequence, etc.), as well as the indices of economic feasibility (profit, return on the capital, etc.) necessary to guarantee the profitability of the industrial utilization of these materials.

\section{Research findings}

\section{Characterization of date palm by-products}

\subsection{Date palm midrib}

\subsubsection{Date palm midrib geometry}

The midrib represents the central part of the palm leaf. Fig.5 illustrates a general view of the palm midrib, divided into three parts: the basal, the middle and the top, as well as the form of the cross-section of its parts. Fig. 6 illustrates the variation of the area of midrib cross section, the diameter of the largest circle drawn within the cross section and its area: from the base of the midrib to the top [24]. Table 2 represents a summary of the weights, lengths and dimensions of the cross sections of midribs of palms of different species (Siwi, Amhat and Balady) in ElFayoum governorate [24]. It is clear that there are significant differences among the species, as well as among different localities for the same species.
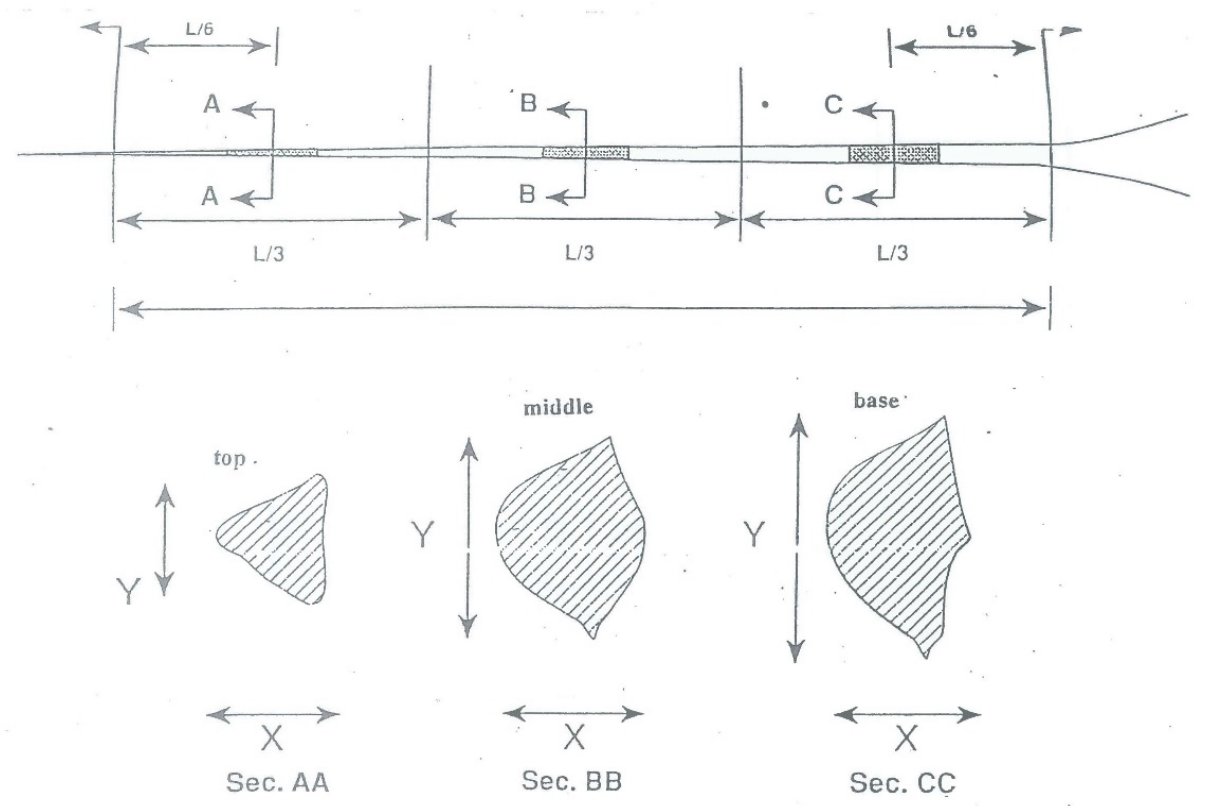

Fig. 5: A diagrammatic sketch showing the palm midrib, as divided to three distinguished parts: base, middle and top [24]. 


\subsubsection{Specific gravity of the palm midrib}

The value of specific gravity was determined for samples taken from the central parts of palm midribs, obtained from the New Valley and Asiut governorates [2]. It was found that these values fluctuate between 0.51 to 0.79 with an average value of 0.66 at a moisture content $\sim 8 \%$. The corresponding value for beech was found to be 0.65 and for spruce 0.35 [2].

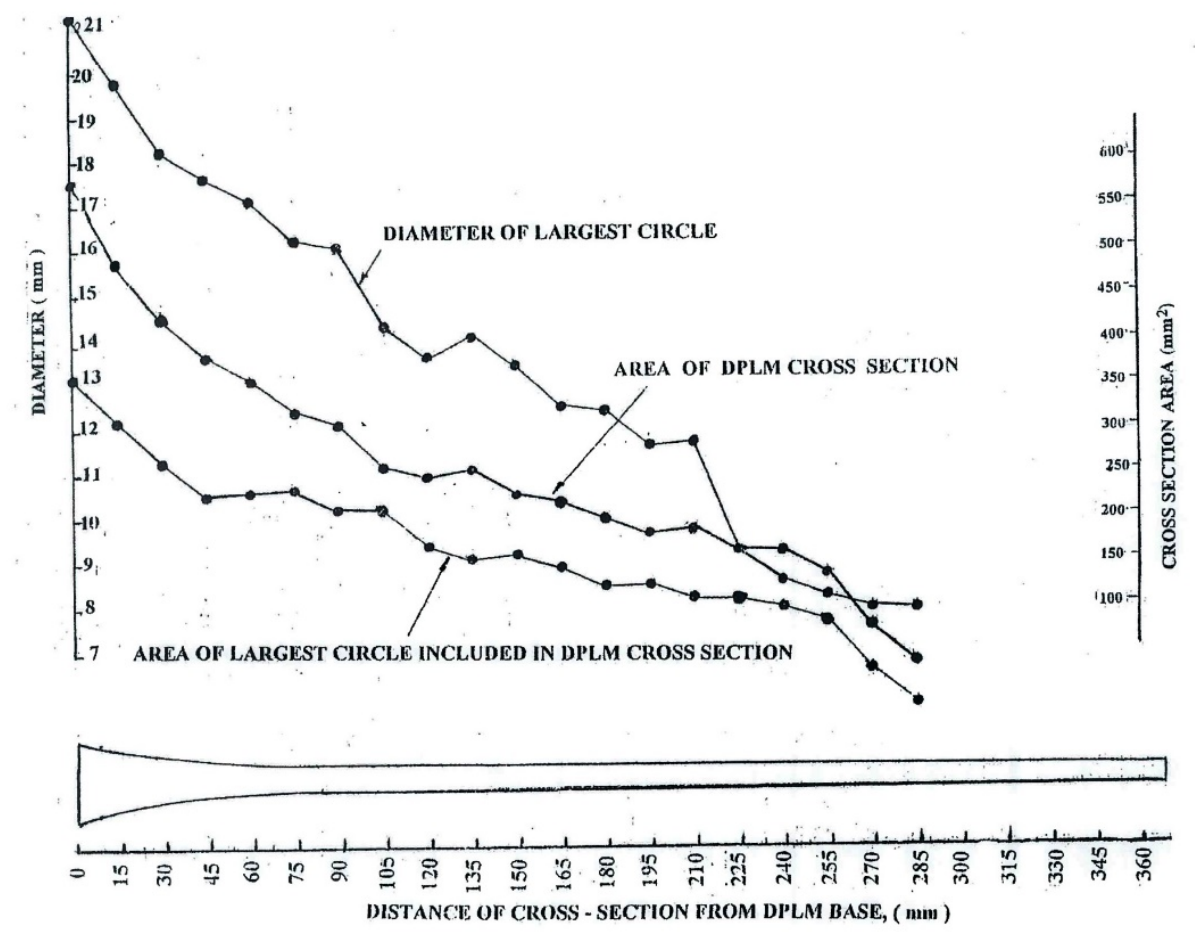

Fig. 6: The variation of cross section, value of the maximum diameter and the area of the largest circle inside the cross section for Siwi palm midribs from the base to the top [23]. 
Table 2: Summary of weights, lengths and dimensions of cross sections for palm midribs (Siwi, Amhat and Baladi species from El Fayoum[24].

\begin{tabular}{|c|c|c|c|c|c|c|c|c|}
\hline \multirow{2}{*}{ Species } & \multirow{2}{*}{ Locality } & \multirow{2}{*}{$\mathrm{n}$} & \multirow{2}{*}{$\begin{array}{r}\text { Weight, } \\
\text { (gm) }\end{array}$} & \multirow{2}{*}{$\begin{array}{r}\text { Length, } \\
(\mathrm{cm})\end{array}$} & \multirow{2}{*}{$\not$} & \multicolumn{3}{|c|}{$\begin{array}{r}\text { Cross section, } \\
\text { dimensions }(\mathrm{mm})\end{array}$} \\
\hline & & & & & & Base & Middle & Top \\
\hline \multirow{2}{*}{ Siwi } & \multirow{6}{*}{ Garfis } & \multirow{2}{*}{22} & \multirow{2}{*}{362} & \multirow{2}{*}{1.62} & $X$ & 17.90 & 15.23 & 12.19 \\
\hline & & & & & $\mathrm{Y}$ & 14.62 & 13.20 & 11.98 \\
\hline \multirow{2}{*}{ Amhat } & & \multirow{2}{*}{14} & \multirow{2}{*}{528} & \multirow{2}{*}{2.05} & $X$ & 20.96 & 16.70 & 13.86 \\
\hline & & & & & $\mathrm{Y}$ & 17.20 & 16.25 & 14.40 \\
\hline \multirow{2}{*}{ Balady } & & \multirow{2}{*}{10} & \multirow{2}{*}{339} & \multirow{2}{*}{1.59} & $X$ & 19.36 & 16.75 & 13.23 \\
\hline & & & & & $\mathrm{Y}$ & 16.38 & 14.19 & 13.00 \\
\hline \multirow{2}{*}{ Siwi } & \multirow{6}{*}{ El-Kaabi } & \multirow{2}{*}{33} & \multirow{2}{*}{381} & \multirow{2}{*}{2.35} & $X$ & 31.87 & 21.48 & 16.78 \\
\hline & & & & & $\mathrm{Y}$ & 26.15 & 18.84 & 17.10 \\
\hline \multirow{2}{*}{ Amhat } & & \multirow{2}{*}{22} & \multirow{2}{*}{629} & \multirow{2}{*}{2.59} & $\mathrm{X}$ & 25.77 & 19.97 & 15.10 \\
\hline & & & & & $\mathrm{Y}$ & 21.91 & 17.37 & 15.72 \\
\hline \multirow{2}{*}{ Balady } & & \multirow{2}{*}{19} & \multirow{2}{*}{493} & \multirow{2}{*}{2.56} & $X$ & 24.51 & 18.83 & 14.81 \\
\hline & & & & & $\mathrm{Y}$ & 20.06 & 16.18 & 15.35 \\
\hline \multirow{2}{*}{ Siwi } & \multirow{6}{*}{$\begin{array}{l}\text { Abou- } \\
\text { Ksah }\end{array}$} & & & & $X$ & 39.78 & 23.27 & 17.07 \\
\hline & & 19 & 657 & 2.73 & $Y$ & 25.42 & 18.84 & 16.26 \\
\hline & & & & & $X$ & 32.90 & 21.90 & 17.83 \\
\hline Amhat & & 21 & 666 & 2.75 & $\mathrm{Y}$ & 23.02 & 18.15 & 15.54 \\
\hline Balady & & 20 & 151 & 252 & $X$ & 27.71 & 19.41 & 15.64 \\
\hline Balady & & 20 & $4 Ь 1$ & 2.52 & $\mathrm{Y}$ & 19.26 & 16.08 & 14.72 \\
\hline
\end{tabular}




\subsubsection{Date palm midrib dimensional stability}

The research findings have shown the high tendency of palm midribs to swell when immersed in water as compared with wood. The percentages of volumetric swelling of midribs of palm of different species (Siwi, Mantour, Tamr and Males) after immersion in water for 38 hours ranged between $980 \%$ for Males and $176 \%$ for Siwi, whereas the corresponding values for wood of different species (beech, spruce, pitch pine and mahogany) ranged between 13\% and 29\% [2].

\subsubsection{Mechanical Properties of Palm Midribs}

The results of tests, conducted on samples taken from the central parts of midribs obtained from different palm species and geographic locations, indicate that the values of mechanical properties of palm midribs vary with the palm species and geographic locations. Table 3 illustrates the results of tests conducted on midribs of palms of Siwi, Amhat and Baladi species in different localities in El Fayoum governorate. The modulus of rupture (MOR) in bending varied from $\sim 70$ for Amhat, 76 for Baladi to $82 \mathrm{~N} / \mathrm{mm}^{2}$ for Siwi palm species. The compressive strength varied from $~ 34$ for Amhat, 36 for Baladi to $\sim 40 \mathrm{~N} / \mathrm{mm}^{2}$ for Siwi. The tensile strength varied from 66 for Amhat, 71 for Baladi to $~ 75 \mathrm{~N} / \mathrm{mm}^{2}$ for Siwi palm species [24].

Table 3: Mean values of the main mechanical properties of palm midribs (Siwi, Amhat and Baladi species from El Fayoum Governorate) [24].

\begin{tabular}{|c|c|c|c|c|c|c|c|c|c|c|}
\hline \multirow{2}{*}{ Species } & \multirow{2}{*}{ Locality } & \multicolumn{3}{|c|}{ Static bending, $\mathrm{N} / \mathrm{mm}^{2}$} & \multicolumn{3}{|c|}{ Comp.//to grain, $\mathrm{N} / \mathrm{mm}^{2}$} & \multicolumn{3}{|c|}{$\begin{array}{c}\text { Tension//to grain, } \\
\mathrm{N} / \mathrm{mm}^{2}\end{array}$} \\
\hline & & $\mathrm{n}$ & MOR & MOE & $\mathrm{n}$ & $\mathrm{CS}_{\max }$ & MOE & $\mathrm{N}$ & UTS & MOE \\
\hline \multirow{7}{*}{ is } & \multirow{2}{*}{ Garfis } & \multirow{2}{*}{13} & 76.17 & 5266 & \multirow{2}{*}{28} & 39.76 & 20.35 & \multirow{2}{*}{22} & 69.23 & 40.61 \\
\hline & & & $(13.40)$ & (1247) & & $(5.30)$ & $(4.92)$ & & $(8.47)$ & $(5.74)$ \\
\hline & \multirow{2}{*}{ El-Kaabi } & \multirow{2}{*}{12} & 76.60 & 4349 & \multirow{2}{*}{17} & 37.66 & 17.18 & \multirow{2}{*}{18} & 79.69 & - \\
\hline & & & $(12.24)$ & $(872)$ & & $(6.12)$ & $(3.57)$ & & $(12.54)$ & \\
\hline & \multirow{2}{*}{ Abou-Ksah } & \multirow{2}{*}{9} & 96.10 & 5731 & \multirow{2}{*}{10} & 44.02 & 19.47 & \multirow{2}{*}{6} & 83.00 & 49.91 \\
\hline & & & $(12.66)$ & (718) & & $(9.89)$ & (4.55) & & $(13.98)$ & $(11.06)$ \\
\hline & $\begin{array}{l}\text { Species } \\
\text { average }\end{array}$ & 34 & 81.6 & & & 39.89 & & 46 & 75.12 & \\
\hline \multirow{7}{*}{$\begin{array}{l}\text { 节 } \\
\text { 是 }\end{array}$} & \multirow{2}{*}{ Garfis } & \multirow{2}{*}{35} & 55.68 & 3648 & \multirow{2}{*}{51} & 30.16 & 13.53 & \multirow{2}{*}{40} & 52.61 & - \\
\hline & & & $(9.04)$ & (831) & & $(11.15)$ & (4.44) & & $(9.45)$ & \\
\hline & \multirow{2}{*}{ El-Kaabi } & \multirow{2}{*}{50} & 77.06 & 5128 & \multirow{2}{*}{64} & 37.35 & 18.66 & \multirow{2}{*}{39} & 76.67 & - \\
\hline & & & $(11.93)$ & (1085) & & $(7.24)$ & (4.56) & & (10.19) & \\
\hline & \multirow{2}{*}{ Abou-Ksah } & \multirow{2}{*}{21} & 73.09 & 5042 & \multirow{2}{*}{56} & 34.08 & 18.07 & \multirow{2}{*}{30} & 71.10 & - \\
\hline & & & (8.50) & (889) & & $(5.37)$ & (4.37) & & $(9.83)$ & \\
\hline & $\begin{array}{l}\text { Species } \\
\text { average }\end{array}$ & 119 & 69.64 & & 171 & 34.13 & & 109 & 66.31 & \\
\hline \multirow{7}{*}{ 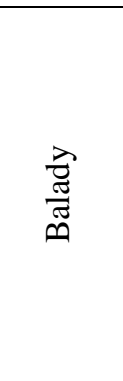 } & Garfic & & 68.26 & 4355 & & 34.01 & 16.75 & & 64.48 & -- \\
\hline & Gartıs & 26 & $(12.28($ & (744) & 43 & $(5.82)$ & (3.39) & 38 & $(9.22)$ & \\
\hline & & & 72.43 & 4946 & & 36.30 & 19.25 & & 73.25 & - \\
\hline & El-Kaabi & 21 & $(8.85)$ & (984) & 32 & $(5.21)$ & $(4.60)$ & 45 & (13.39) & \\
\hline & & & 88.98 & 6096 & 27 & 38.98 & 39 & & 76.20 & \\
\hline & Abou-Ksah & 22 & $(11.42)$ & (955) & 27 & $(4.67)$ & (4.53) & 39 & (14.65) & \\
\hline & $\begin{array}{l}\text { Species } \\
\text { average }\end{array}$ & 69 & 76.14 & & 102 & 36.04 & & 122 & 71.46 & \\
\hline
\end{tabular}


- Means with the same letters are not significantly different according to Duncan's multiple range test $(p=0.05)$, values in parenthesis represent standard deviations, and $n$ is the number of specimens.
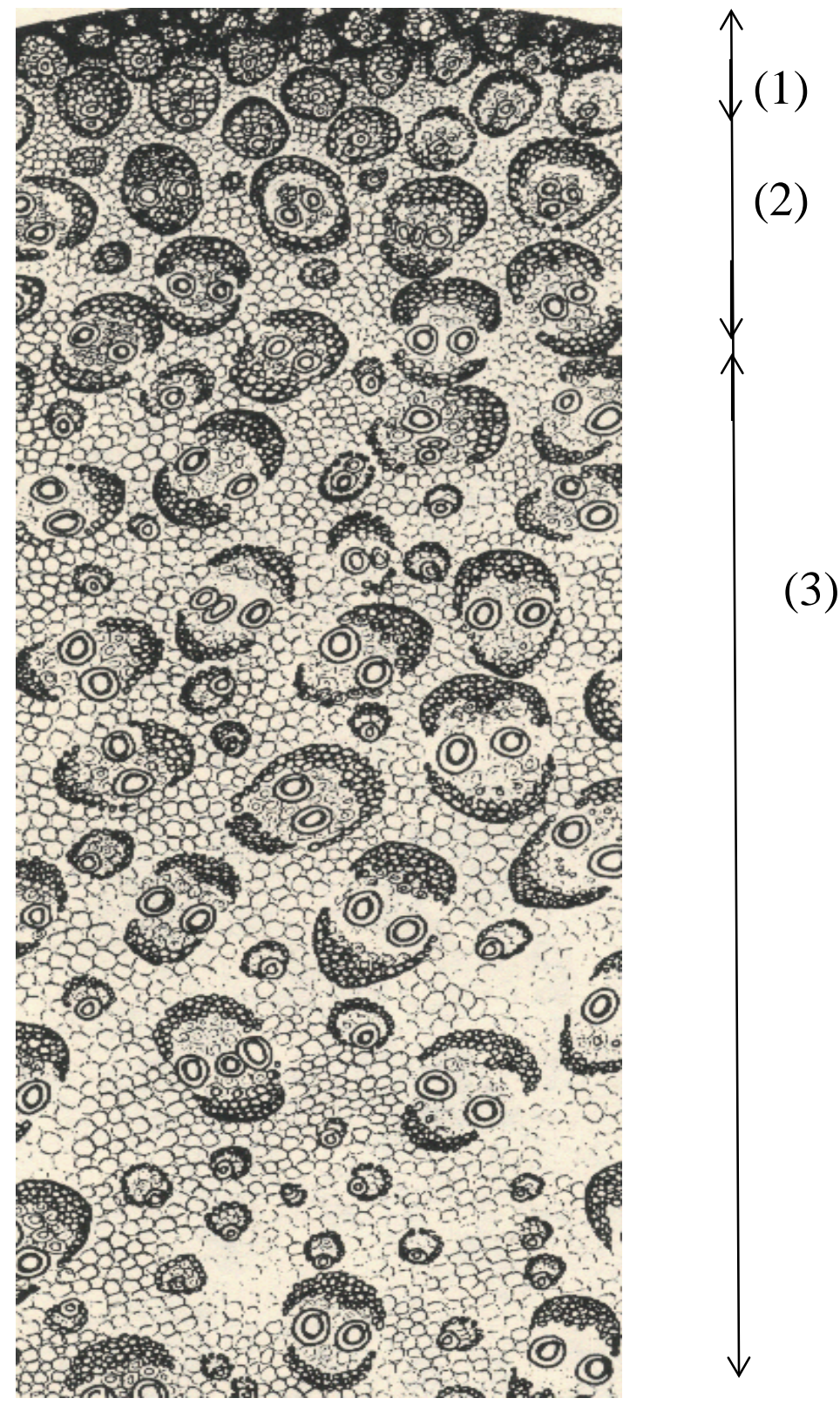

Fig. 7: A diagrammatic illustration of a transverse section of the palm midrib showing the peripheral (1), transitional (2) and core zone (3) (25X) [38]. 


\subsubsection{The Anatomical ${ }^{(2)}$ Study of the Palm Midrib}

A study has been conducted on the anatomy of the midrib, (Fig. 7), [24]. This study has shown that the palm midrib belongs to the class of monocotyledons, where cross linking is absent in the cross section. The fibro-vascular bundle is the structural unit of the cross section. The cross sectional area of the fibro-vascular bundles, as well as the density of their distribution differ greatly from the epidermal layer to the core of the midrib. In was possible in this study to classify the midrib cross section into three regions: peripheral, transitional and core layers.

It was possible to evaluate the thickness of both the peripheral and transitional layers, where the ratio of fibers increases with adherence to the periphery, by $\sim 1.25 \mathrm{~mm}$. It was also possible to evaluate the average length of fibers by $1.366 \mathrm{~mm}$ for Baladi midribs and $1.288 \mathrm{~mm}$ for Siwi midribs.

\subsection{Date Palm Leaflets}

The leaflets emerge on both sides of the midrib of the palm leaf. Fig. 8 illustrates the external view of the leaflet. The leaflet represents a green blade resembling the sward bending longitudinally in its middle and having a swell at its base, where the leaflet is connected with the midrib.

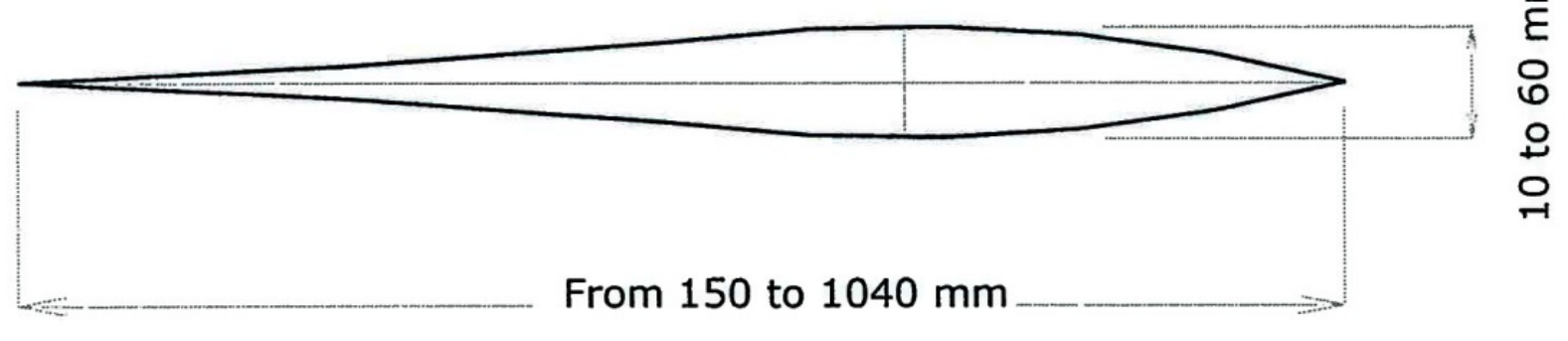

Fig. 8: A diagrammatic sketch illustrating an overall view of the leaflet [7].

\subsubsection{Dimensions, Density and Mass of Leaflets}

A study has been conducted on the leaflets of Siwi palms from Giza governorate [7].

\section{The following results were obtained:}

- $\quad$ Number of leaflets in one midrib varies: from 166 to 197 with an average of 176.

- $\quad$ The width of the leaflet changes from zero at the top to its highest value near the base ranging from 10 to $60 \mathrm{~mm}$ as shown in Fig. 8.

- $\quad$ The thickness of the leaflet varies from 0.305 to $0.508 \mathrm{~mm}$ with an average of $\sim 0.4$ $\mathrm{mm}$.

- The density of the leaflets at moisture content $12 \%$ is equal to $0.56 \mathrm{gm} / \mathrm{cm}^{3}$.

2 - This study has been conducted in the department of Forestry, the Faculty of Agriculture, Alexandria University by Prof. Dr. M.M. Megahed. 
- $\quad$ The mass of the leaflets for each midrib is equal to $\sim 0.5 \mathrm{~kg}$ (at a moisture content of $12 \%)$.

\subsubsection{Mechanical Properties of Leaflets}

Fig. 9 illustrates a comparison between the values of the tensile strength for leaflets taken from different palm species: Males, Mantour, Saeidy, Sohagi (dry and green). It is evident from this figure that these values range from 50 to $120 \mathrm{~N} / \mathrm{mm}^{2}$ and thus fall within the same range of the corresponding values of the palm midrib.

\subsubsection{Anatomical Study of the Leaflets}

An anatomical study has been conducted on the leaflets of Balady palms, brought from Giza governorate [24]. Fig. 10 illustrates a section in a leaflet showing the pattern of distribution of the fibro-vascular bundles. This study has shown that the average fiber length in the leaflets is $1.181 \mathrm{~mm}$, which falls within the same range of averages for the clade of dicotyledons and hardwoods and softwoods and less than that of the palm midrib $(1.325 \mathrm{~mm})$.

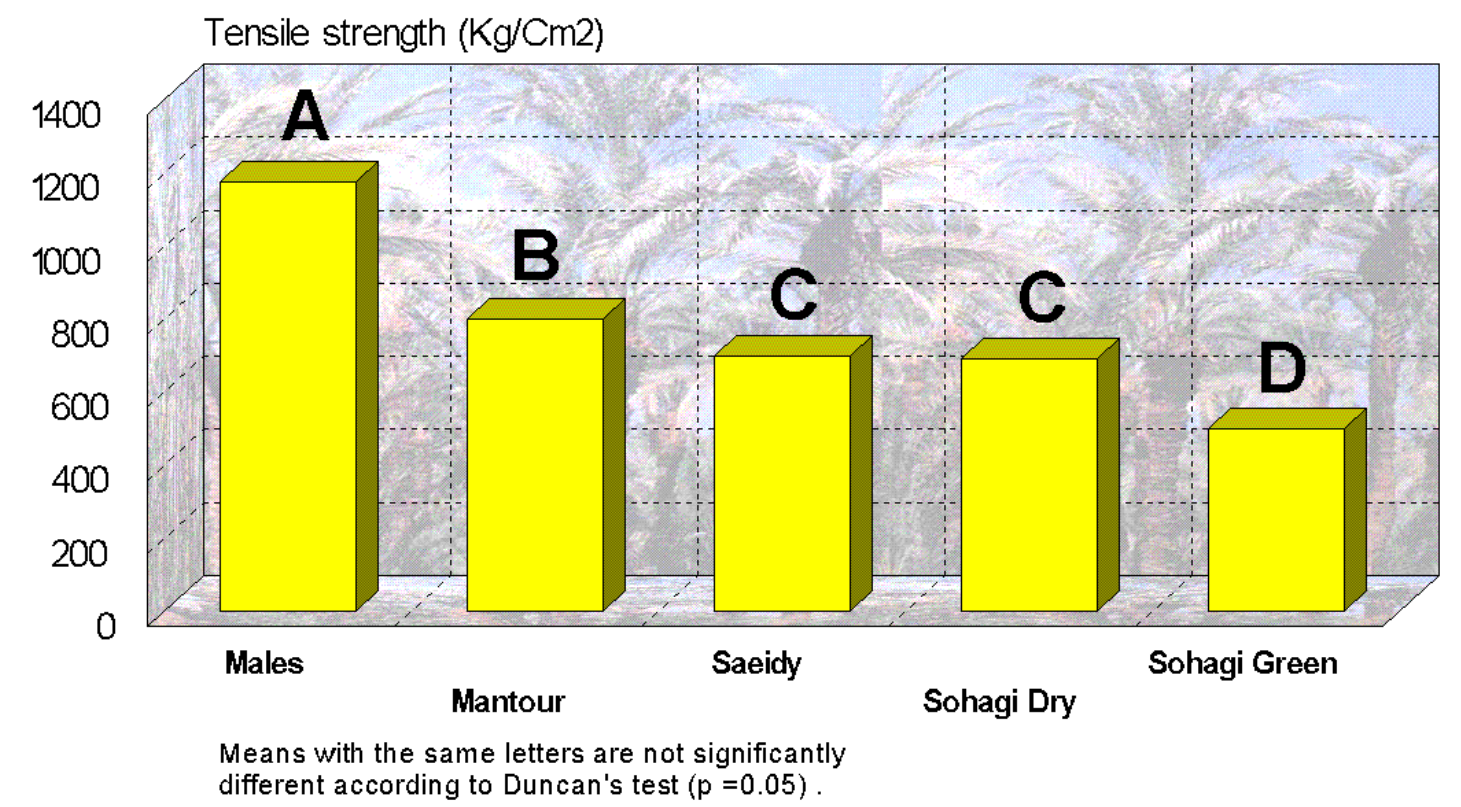

Fig.9: Comparison between the values of tensile strength for leaflets taken from palms of different species: males, Mantour, Saeidy (Siwi) and Sohagi dry and green [7]. 


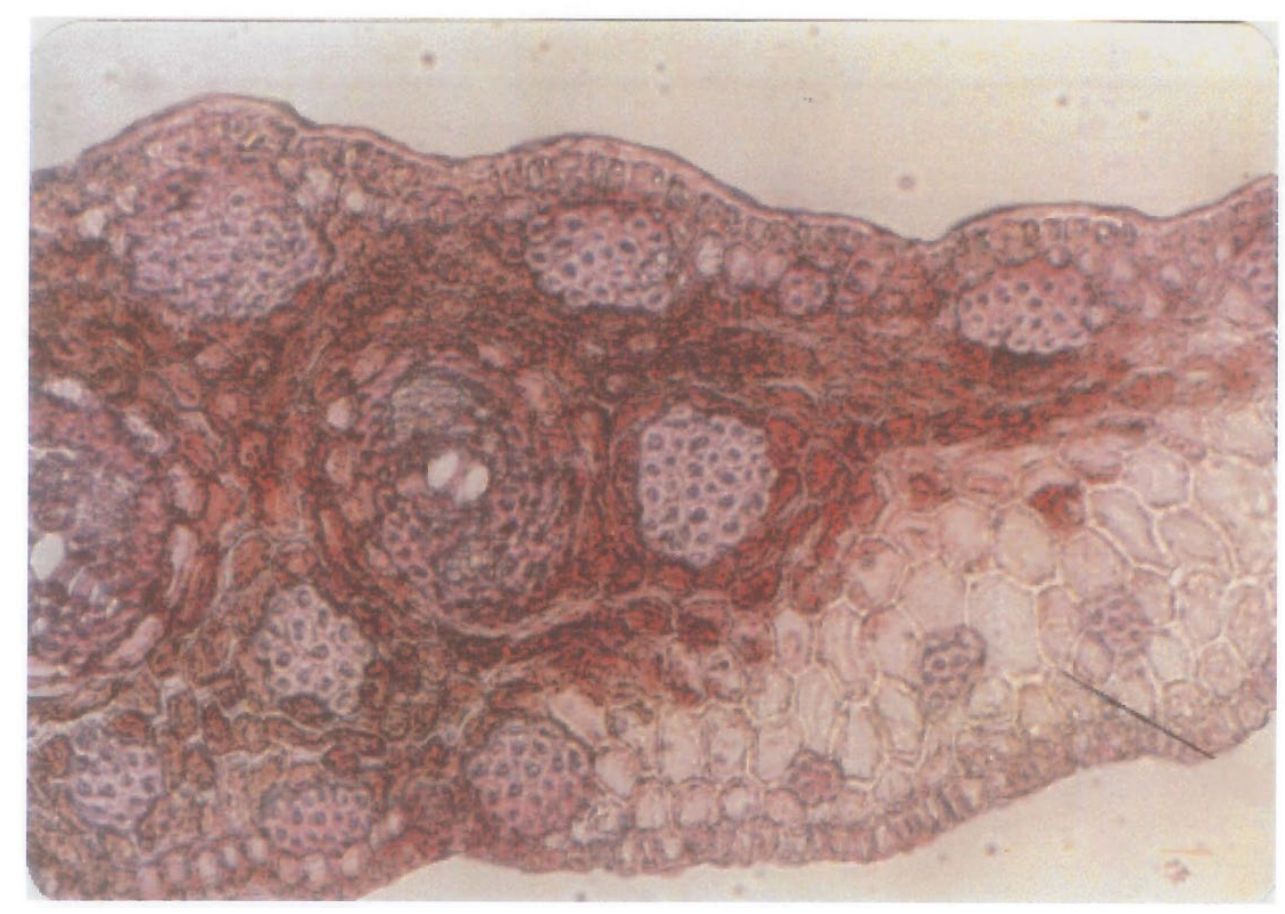

Fig.10: A cross section in the leaflet illustrating the distribution of fibro-vascular bundles (26X) [24].

\subsection{The Spadix Stem \\ 1.3.1. Spadix Stem Geometry}

The spadix stem carries the date amounting to more than $40 \mathrm{~kg}$. The length of the spadix stem ranges from 1-2 meters. Its cross section has the form of an ellipse with a total area of about 500 $\mathrm{mm}^{2}$.

\subsubsection{The Anatomical Study of the Spadix Stem}

An anatomical study has been conducted on a spadix stem from Balady palm, taken from Giza governorate [24]. Fig. 11 illustrates a cross section in the spadix stem. It is clear that the intensity of the fibro-vascular bundles increases and their diameter decreases and the ratio of fibers increases as we move from the core to the periphery. The study has shown that the average value of fibers length in the spadix stem is about $1.114 \mathrm{~mm}$, which falls within the average values of the clade of dicotyledons and the hardwoods and softwoods and less than that of palm midrib fibers $(1.325 \mathrm{~mm})$. 


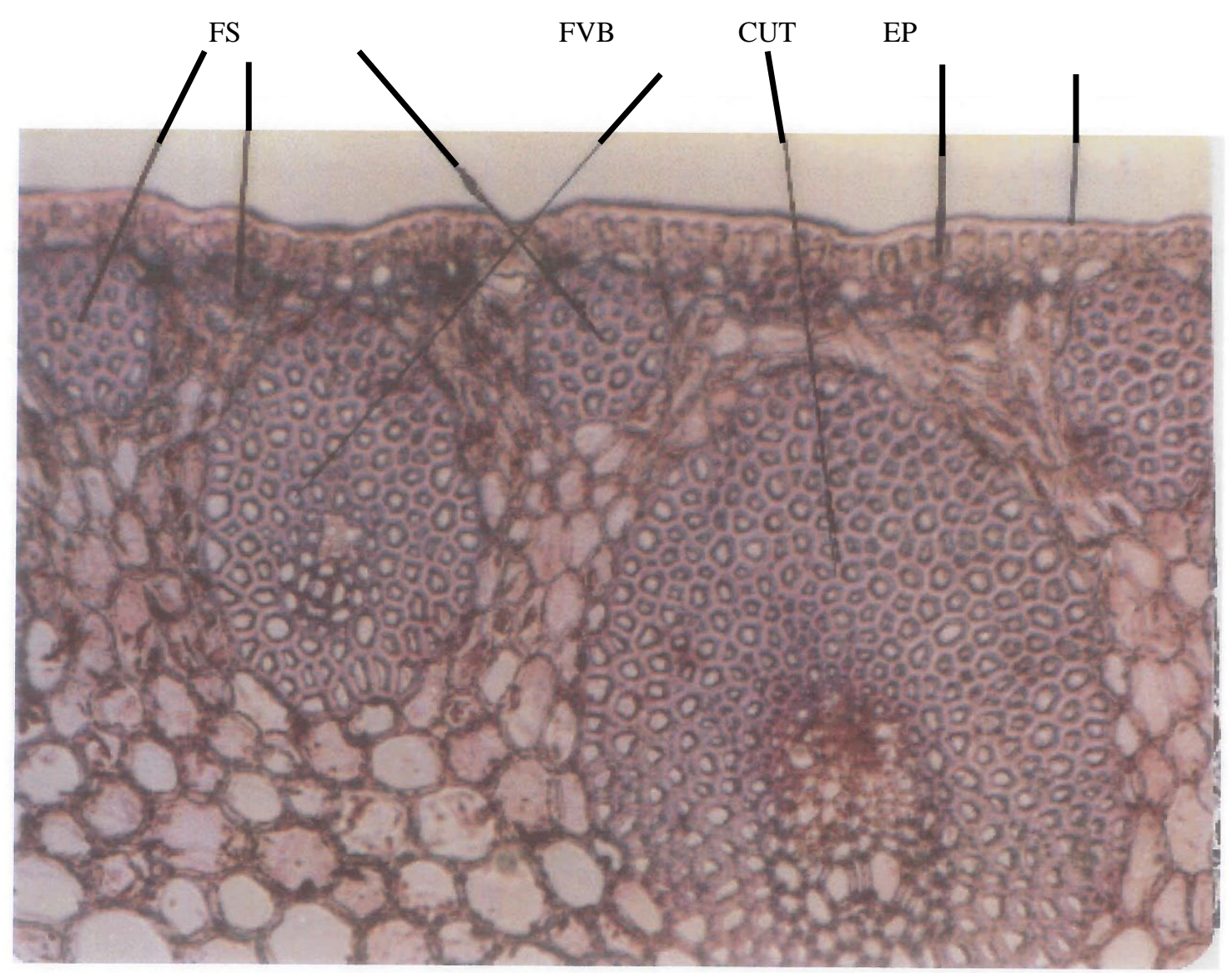

Fig. 11: Photomicrograph of transverse section of date palm spadix stem in the outer zone showing cuticle layer (CUT), epidermis (EP), cortex, fiber strands (FS) and outer fibro-vascular bundles (FVB) (265X) [24].

\subsubsection{Coir}

The base of the midrib is linked to the trunk by a sheath of coir surrounding the whole trunk. The coir sheath consists of white tissues interspersed by fibro-vascular bundles [24]. With the growth of the palm leaf most of the white tissues disappear leaving the dry dark fibro vascular bundles forming a coarse rough sheath surrounding the trunk. This sheath should be seasonally pruned, otherwise it may increase the danger of fire in the palm garden due to its high susceptibility to fire, especially in the dry state.

\subsubsection{Mechanical Properties of Coir}

The tensile strength was measured for a coir cord [3] and was found to be $\sim 60 \mathrm{~N} / \mathrm{mm}^{2}$. This value falls within the range of the corresponding values for the palm midrib. 


\subsubsection{The Anatomical Study of Coir}

An anatomical study has been conducted on the coir of a Balady palm. The results of this study [24], have shown that the average length of fibers of coir is $\sim 1.143 \mathrm{~mm}$, which falls within the same range of dicotyledons and hardwoods and softwoods and shorter than that of the palm midrib (1.325 mm).

\subsection{Date Palm Trunk Mechanical Properties}

Three points bending test has been performed on air dried specimens of size 50 x 20 x $450 \mathrm{~mm}$ from palm trunk, red European pine and beech (3 similar specimens from each material). The span length was $400 \mathrm{~mm}$. The test was performed on a universal testing machine at a crosshead speed of $5 \mathrm{~mm} / \mathrm{min}$ in compliance with ASTM D1037-72.

The results of tests are shown in Table (4). It is clear from this table that the palm trunk has an overage bending strength amounting to $82.4 \mathrm{MPa}$, which is $15 \%$ lower than red European pine and $36 \%$ lower them the beech wood. The value of the Young's modulus in bending of the palm trunk is $6311.6 \mathrm{MPa}$, which is about $19 \%$ lower than red European pine and $31 \%$ lower than beech wood. This opens the potentiality of using date palm trunks as a substitute for imported wood. This may help in satisfying the basic needs of millions of people in Southern countries of furniture doors, windows, etc. at a much lower cost and without cutting trees from forests leading to the green house phenomenon and global warming.

\subsection{Comparison Between Some Physical and Mechanical Properties of Date Palm by- products}

Table (5) illustrates a comparison between some physical and mechanical properties of date palm by-products, as well as with known wood species (e.g. beech, pine and spruce).

Table (4): The average bending strength, and Young's modulus in bending for the date palm trunk and other wood species.

\begin{tabular}{|c|l|l|l|}
\hline No & \multicolumn{1}{|c|}{ Sample Name } & \multicolumn{1}{|c|}{$\sigma_{\mathrm{b}}(\mathrm{MPa})$} & \multicolumn{1}{c|}{$\mathrm{E}_{\mathrm{b}}(\mathrm{MPa})$} \\
\hline 1 & Trunk & $82.412(13.59)$ & $6311.638(974.34)$ \\
\hline 2 & RED European pine & $97.144(16.32)$ & $7807.751(1524.57)$ \\
\hline 3 & Beech & $128.52(29.27)$ & $9176.618(1212.68)$ \\
\hline
\end{tabular}


Table 5: Comparison between physical and mechanical properties of date palm by-products [2].

\begin{tabular}{|c|c|c|c|c|c|c|c|c|c|}
\hline \multirow[b]{2}{*}{ No. } & \multirow[b]{2}{*}{ Туре } & \multirow{2}{*}{$\begin{array}{c}\text { Fiber } \\
\text { length, } \\
\text { mm }\end{array}$} & \multirow[b]{2}{*}{$\begin{array}{l}\text { Specific } \\
\text { wt. }\end{array}$} & \multicolumn{2}{|c|}{ Static bending } & \multicolumn{2}{|c|}{$\begin{array}{c}\text { Tension test parallel to } \\
\text { fibers }\end{array}$} & \multicolumn{2}{|c|}{$\begin{array}{c}\text { Compression test parallel } \\
\text { to fibers }\end{array}$} \\
\hline & & & & $\begin{array}{l}\text { Mod. Of } \\
\text { elasticity, } \\
\mathrm{N} / \mathrm{mm}^{2}\end{array}$ & $\begin{array}{c}\text { Mod. Of } \\
\text { Rupture, } \\
\text { N/mm }\end{array}$ & $\begin{array}{c}\text { Mod. Of } \\
\text { elasticity } \\
\mathrm{N} / \mathrm{mm}^{2}\end{array}$ & $\begin{array}{c}\text { Tensile } \\
\text { strength, } \\
\text { N/mm² }\end{array}$ & $\begin{array}{l}\text { Mod. Of } \\
\text { elasticity } \\
\mathrm{N} / \mathrm{mm}^{2}\end{array}$ & $\begin{array}{c}\text { Max. } \\
\text { compressive } \\
\text { strength } \\
\mathrm{N} / \mathrm{mm}^{2}\end{array}$ \\
\hline 1 & $\begin{array}{l}\text { Midribs } \\
\text { (different species) }\end{array}$ & $\begin{array}{c}1.29- \\
1.37\end{array}$ & $\begin{array}{c}0.51-0.79 \\
\text { (average } \\
0.66 \text { ) }\end{array}$ & 69.6-81.6 & $\begin{array}{c}3648- \\
6096\end{array}$ & $66.3-75.1$ & - & 34.1-39.9 & - \\
\hline 2 & Leaflets & 1.18 & 0.56 & - & - & $50-120$ & - & - & - \\
\hline 3 & Palm trunks & - & 0.48 & 38 & - & - & - & - & - \\
\hline 4 & Spadix stem & 1.1 & - & - & - & - & - & - & - \\
\hline 5 & Coir & 1.14 & - & - & - & - & - & - & - \\
\hline 6 & Beech wood [2] & - & 0.65 & 137 & 11700 & 97 & - & 74 & - \\
\hline 7 & Scots Pine wood [47] & - & 0.53 & 98 & 11760 & 102 & - & 54 & - \\
\hline 8 & Spruce wood [2] & - & 0.35 & 93 & 9300 & 47 & - & 42.5 & - \\
\hline
\end{tabular}




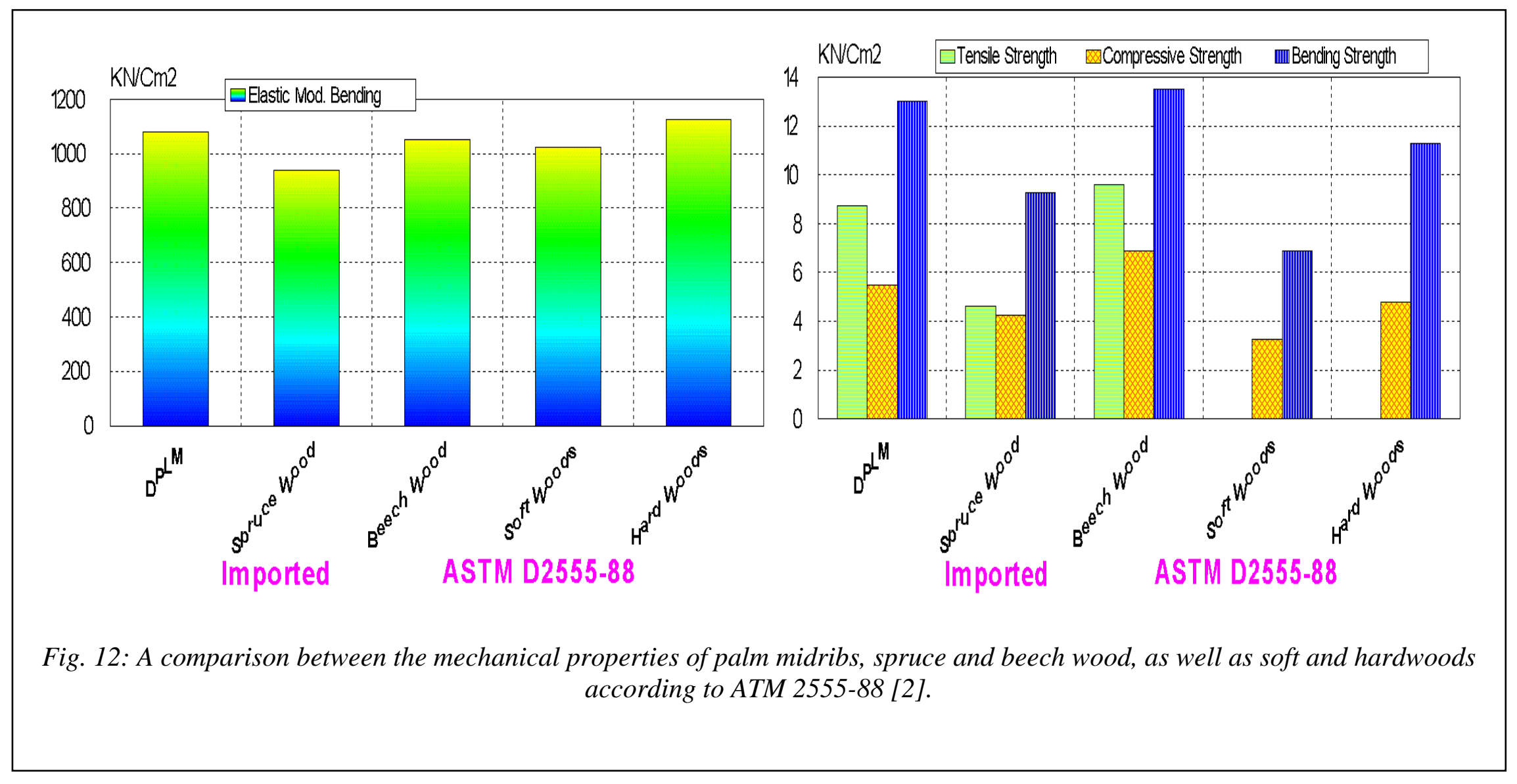




\subsection{Study of Insects Attacking Palm Midribs}

A study has been conducted to diagnose the most prominent insects attacking the palm midrib (midrib borers) and seasons of severe infestation, as well as to find out the most appropriate means for protection from - and struggle against - infestation [8]. The most important of these midrib borers were found to be:

- $\quad$ Phonapate Frontalis

It is an insect of large size of length $\sim 15 \mathrm{~mm}$ having, two projecting toothed anvils protruding forward, beside many short sharp ends in its frontal part. It is of black color and the infestation takes the form of big corridors leading to the fracture of the midrib.

- $\quad$ Enneadesmus Trispinosus

It is an insect of length 3 millimeters and is dark brown in color. The appearance of infestation takes the form of round holes $1 \mathrm{~mm}$ in diameter, beside the existence of corridors inside the midrib as well as the appearance of "flour" near to the corridors, made by the insect.

\section{Industrial Applications and Products From Date Palm by-products \\ 2.1.1. Use of Palm Midrib as a Core Material in Blockboards}

Why we chose this topic of research? The blockboard is highly needed in Egypt for the manufacture of high quality furniture, as well as wall and ceiling paneling, interior fittings, etc. The local blockboard industry could satisfy only $15 \%$ of the local demand, the rest being imported. We found that this industry is in a shaky position, because it totally relies on imported wood, the price of which is continuously increasing due to the success of environmental movements world-wide putting increasing pressure on the cutting of wood from forests. The research, conducted by the faculty of engineering, Ain Shams Univ. collaboration with the Academy of Scientific Research and Technology has proven that the date palm midrib enjoys mechanical properties comparable with those for imported wood (e.g. spruce and beech) (Fig. 12) If we take a blockboard of thickness $16 \mathrm{~mm}$; the wood core layer will be $\sim 13 \mathrm{~mm}$. Here comes the spark of rediscovery of the palm midrib: could we replace the inner core of the blockboard with palm midribs and thus save $~ 80 \%$ of the wood being imported?. Thus, a master thesis has been registered with the headline: "A Study on the Appropriate Conditions of the Press-cycle for the Manufacture of Palm-midrib Core Blockboards [37]. The appropriate conditions of the press cycle were determined and found as follows:

Pressure: $0.8 \mathrm{~N} / \mathrm{mm}^{2}$, temperature $120^{\circ} \mathrm{C}$

Press time: 5 minutes [37].

Side by side with conducting research the Centre for Development of Small-Scale Industries, Ain-Shams University launched a project for the establishment of a blockboard pilot unit in ElKharga, the New Valley Governorate by a grant from GTZ. The date palm midrib core blockboard specimens were sent to Munich Institute for wood Research in Aachen University. The results of tests indicate that the date palm midrib core blockboard has excellent quality according to DIN standards (DIN 52375, 52364, 53374, 53255, 52371 and 68705) and can be used as a substitute for spruce-core blockboards: in furniture, wall and ceiling paneling, containers, equipment, etc. (Appendix 1). 
The production of the blockboard pilot unit has been utilized by the UNICEF for the manufacture of furniture for 100 community schools in Asiut, Souhag and Kena governorates in 1995: The UNICEF was very satisfied with the results (Appendix 2).

\subsubsection{Lumber-like Products from Palm Midribs}

We were contemplating our success in the palm midrib-core blockboard. We had to use wooden veneers from both sides to manufacture the blockboard. How could we dispense with the wooden veneers? This line of thinking brought us to the idea of manufacture of lumber-like blocks from palm midribs. Therefore, a master thesis has been accomplished with the title: "An Investigation Into the Conditions of Manufacture of Lumber-Like Blocks From Date Palm Leaves Midribs" [46]. It was found that the appropriate conditions of manufacture are:

$$
\begin{aligned}
& \text { Pressure }=0.09 \mathrm{~N} / \mathrm{mm}^{2} \\
& \text { Press time }=1 \text { hour }
\end{aligned}
$$

The comparison between main mechanical properties of palm midrib blocks (e.g. modulus of rupture, modulus of elasticity, maximum compressive strength and nail pull through tests) and those for spruce and beech show that the results are comparable (Fig. 13). This research has been accredited the prize of the best poster in Euromat-97 conference (Appendix 3).

\subsubsection{Super-Strong Materials from Palm Midribs}

The study of anatomy of the palm midrib (see item 7.1.2.3) has shown that the peripheral layer greatly differs from the core layer, whereby the former is distinguished with a high density of the fibro-vascular bundles and the smallness of their diameter. This gives an indication that the palm midrib peripheral layer enjoys high mechanical properties as compared with the core material. This was the springboard of a study made on the mechanical properties of the palm midrib peripheral layer with the purpose of finding a new area of utilization of this layer being a secondary product in the blockboard industry using the palm midrib as a base material. The results of this study [28], (Fig. 14), show that the palm midrib external layer with a thickness $1.25 \mathrm{~mm}$ enjoys a tensile strength of $\sim 250 \mathrm{~N} / \mathrm{mm}^{2}$. As far as the specific tensile strength (tensile strength per unit mass) is concerned this superstrong material exceeds St. 37 by more than 4 times, which opens a new area for its use in biocomposites to substitute other non-renewable materials, such as glass fibers.

\subsubsection{Mashrabiah Products from Palm Midribs}

How did the idea of use of palm midribs in Mashrabiah (Arabesque) come to our minds? The Mashrabiah (Arabesque) was being intensively used in houses in Egypt and the Arab World. It helps in preserving the privacy of dwellers and in ameliorating the harshness of sun rays, while allowing at the same time to have a look from windows on the outside world. The drastic increase in prices of imported beech wood has led to the shrinkage of demand on Mashrabiah (Arabesque) products. We were conducting machinability tests on palm midrib samples on metal-cutting centre lathes. The date palm midrib piece reached a diameter of $\sim 2 \mathrm{~mm}$ without breakage. This means that palm midrib is strong enough to replace wood. Thus, the idea came to us (again the rediscovery of material resources): why wouldn't we go to remote villages possessing palm plantations and teach the populace there how to make Arabesque products that may replace wooden Arabesque products? The idea looked fantastic: reviving the traditional skills of Arabesque manufacture to support the Mashrabiah as a distinguishing component of our traditional way of life, while providing sustainable labor opportunities in remote villages, where women could work on lathes at their houses. 


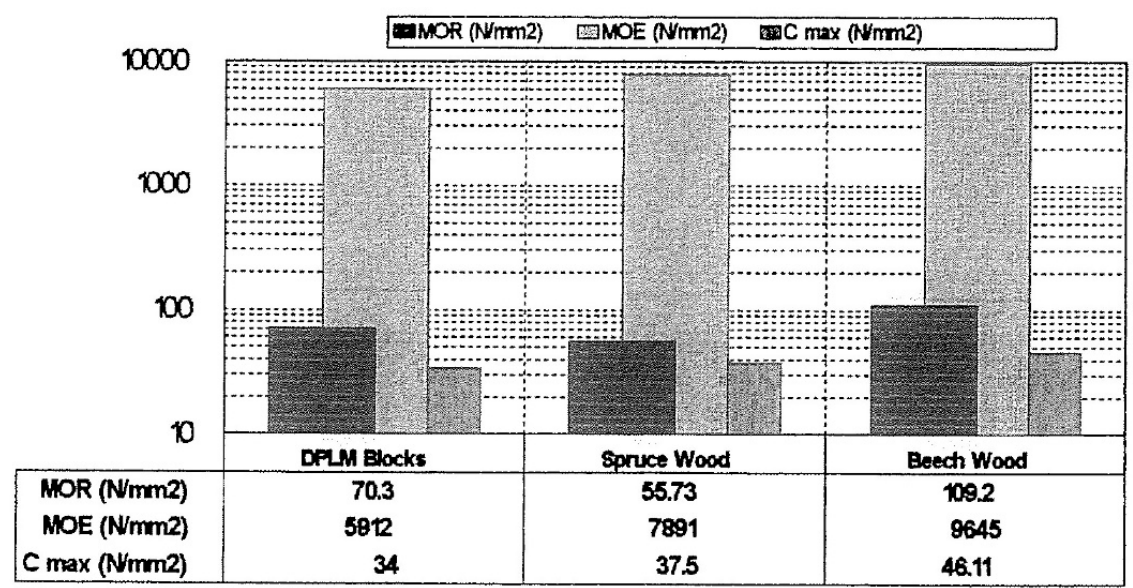

(a)

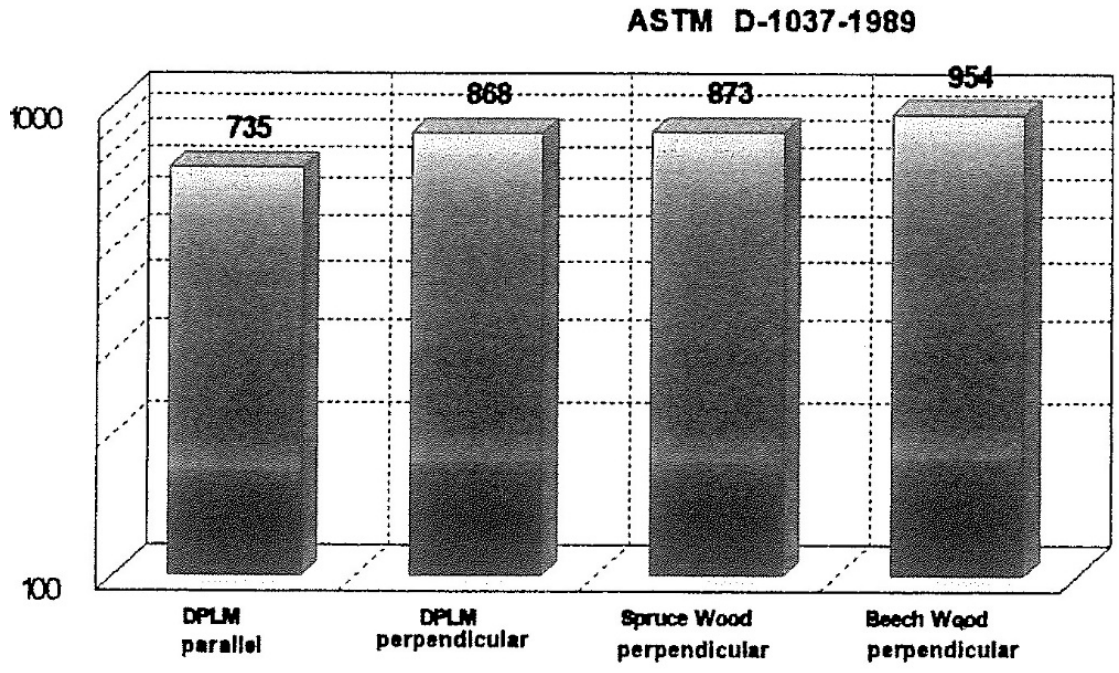

(b)

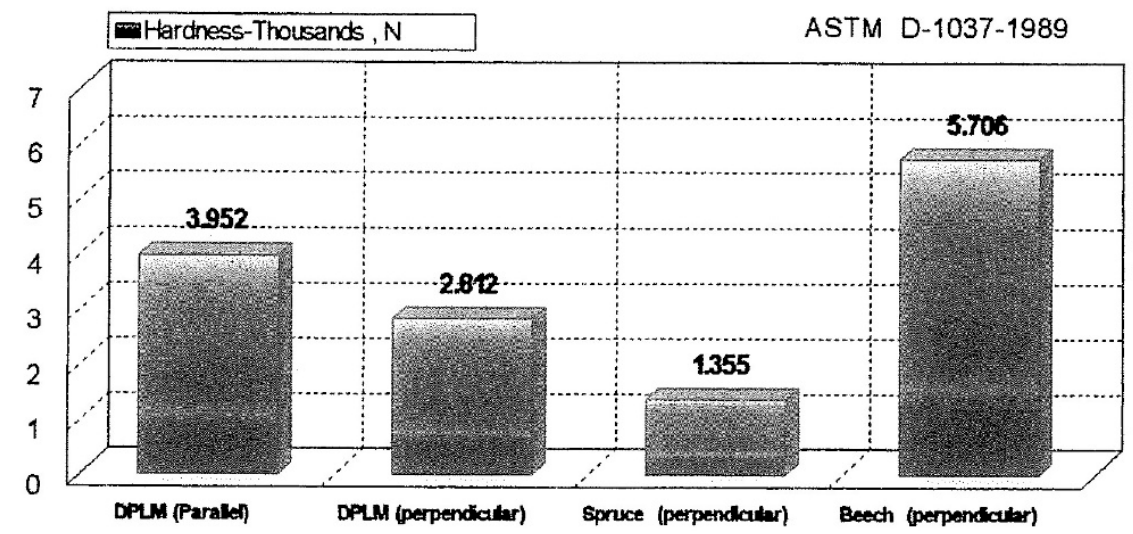

Fig. 13: A comparison between the mechanical properties of lumber like blocks from palm midribs and other species of wood: (a) bending strength, modulus of elasticity and compressive strength Cmax, (b), nail withdrawal resistance and (c) hardness [46]. 


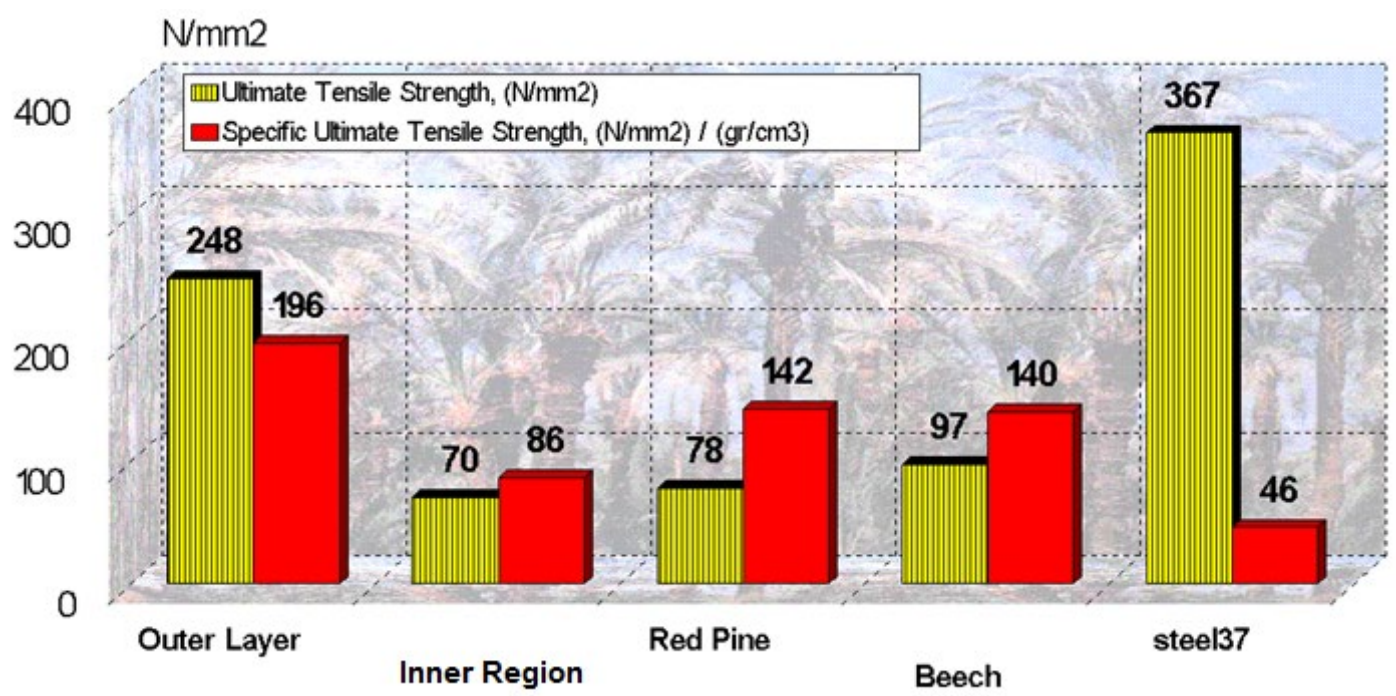

Fig.14: A comparison between the ultimate tensile strengh and specific tensile strengh of palm midribs (peripheral and core layers), red pine and beech wood and steel 37 [28].

The Gedeida village in El-Dakhla oases was chosen as a site of the project, which was launched by the Centre for Development of Small-Scale Industries, Ain Shams Univ. by a grant from GTZ. A new multi-purpose machine has been especially designed for this project, tailored to the needs of beneficiaries to work at home (Fig. 15). The machine could perform turning, drilling, saw cutting of palm midribs, in addition to turning solid pieces of local wood species. A training center has been established to secure palm midribs for beneficiaries, prepare palm midrib pieces and train beneficiaries (Fig. 15), as well as a permanent exhibition to help in marketing of products. Fig. (16) illustrates samples of arabesque products from palm midribs.

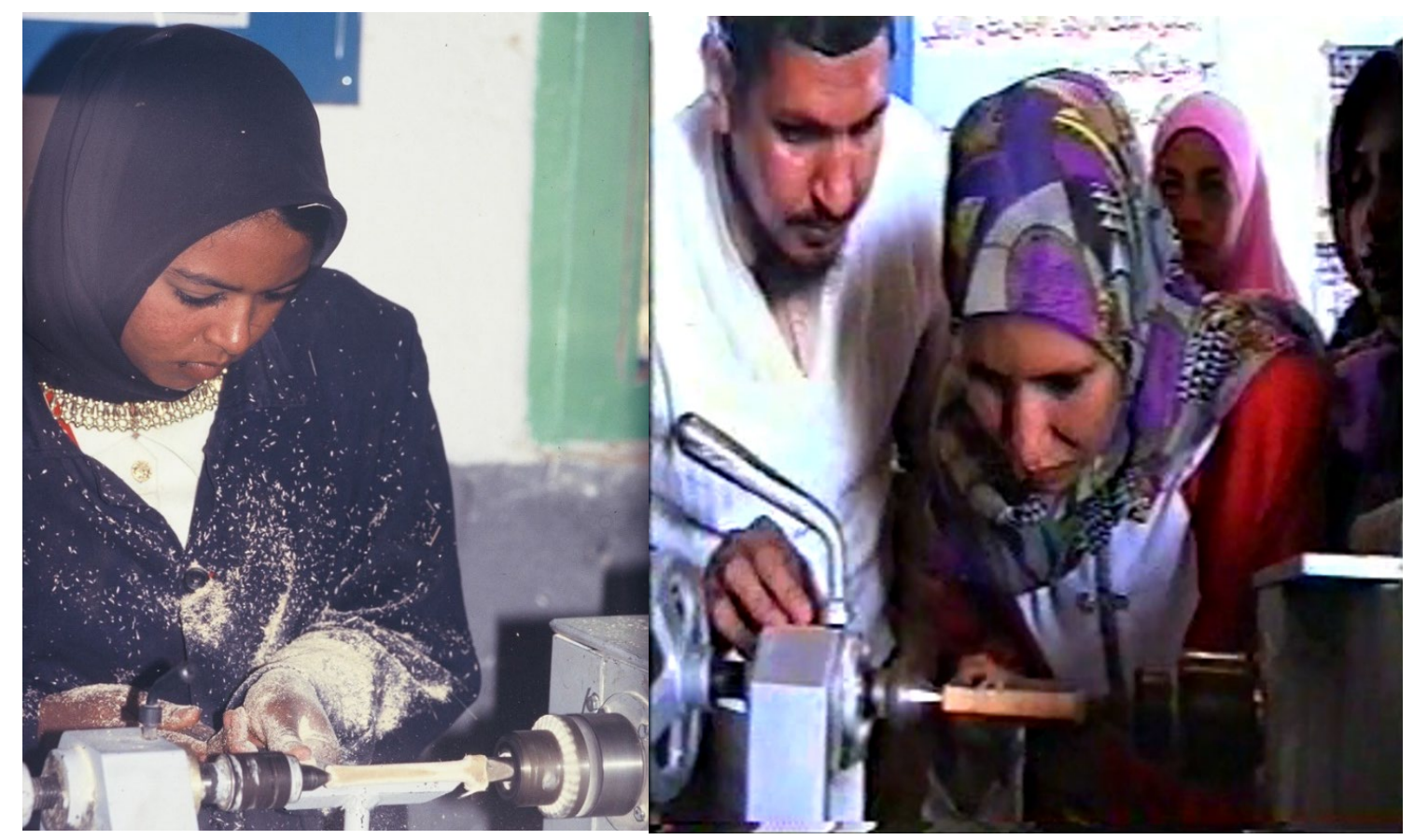

Fig.15: Training of women on manufacture of Arabesque products from palm midribs. 


\subsection{Organic Products from Palm Midribs}

\section{What are the arguments behind this line of research?}

1. The organic products from palm midribs mean that you are making use to the maximum of the inherent structural properties of the palm midribs. The anatomical study of the palm midrib (Fig. 7) points to the increase of the intensity of the fibro-vascular bundles and fibers and consequently the strength, as we approach the peripheral zone, i.e., the strength of the palm midrib in its natural state will be certainly higher that of the core, found by research to compete with the imported wood.

2. The manufacture of organic products from palm midribs means that you are beginning the first life cycle from the top of cascade of utilization (Fig. 17). This gives the chance for subsequent life cycles for example in Arabesque, particleboard and fiberboard, etc. This is a good example of application of the full utilization principle [4].
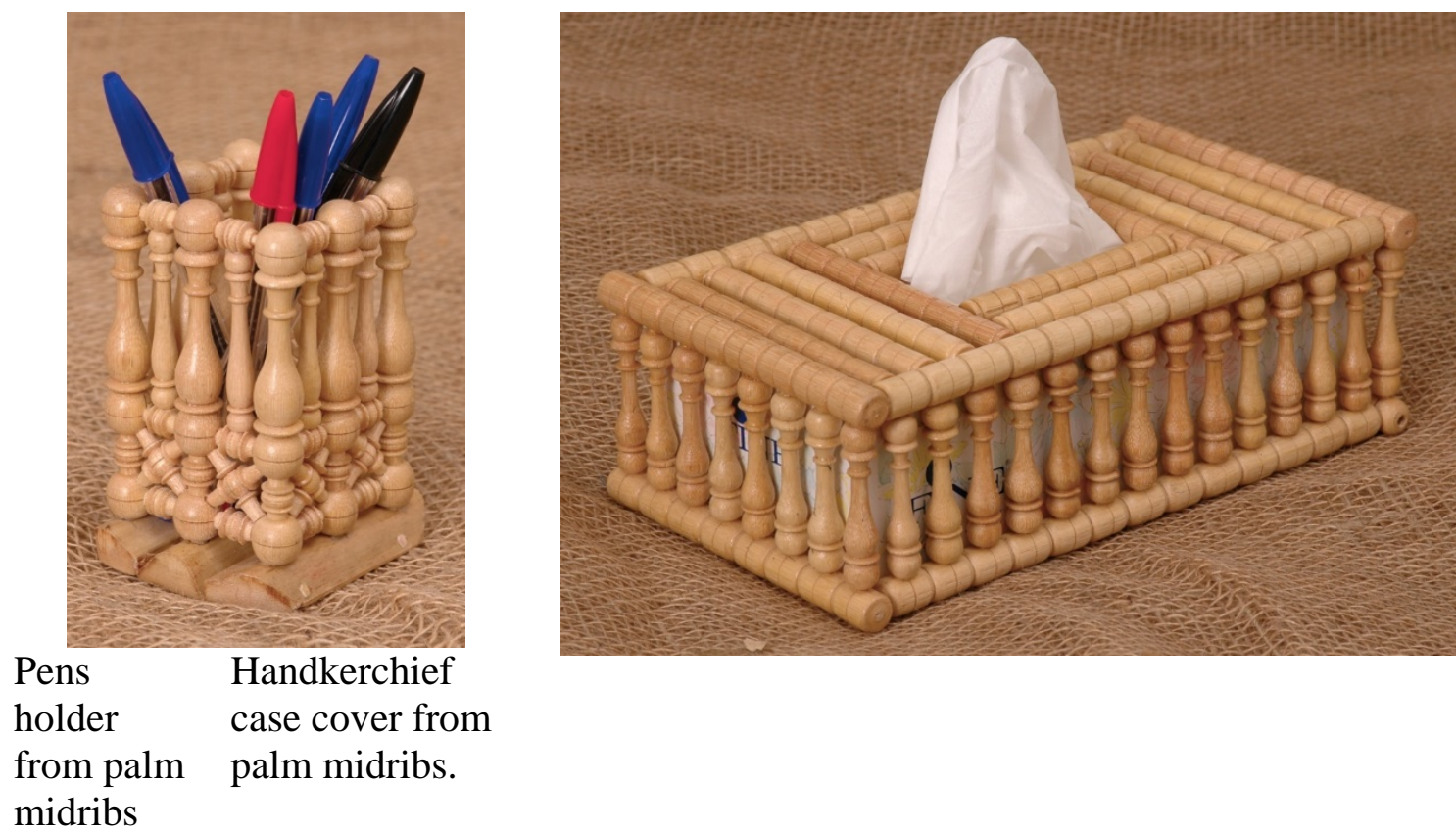

Fig. 16: Mashrabiah (Arabesque) products from palm midribs

3. This application will provide the chance to make use of distinguishing physical properties of palm midribs. For example, the epidermal layer of the palm midrib is not porous, which makes it water resistant, in addition to its being covered by a layer of natural wax protecting it from dehydration in the conditions of aridity of the Arab region, where palms grow. This means that the organic products from palm midribs will enjoy a high water resistance without using paints or chemicals, as well as good insulation properties.

4. From a life cycle perspective [33], the organic products from palm midribs enjoy considerable environmental advantages, since the net energy requirement for their manufacture is minimal as compared with other fields of manufacture of palm midribs. In addition, these products are totally biodegradable, i.e., they will not represent any problem during the disposal stage, since they could be used as filling material to be added to the fodder, for poultry [34], and livestock [30], or burned as a $\mathrm{CO}_{2}$-neutral material [18]. 
5. The organic products from palm midribs represent an eloquent example of use of the ecological specificity of our region as a strategic comparative advantage. The palm midrib carries the imprint of the local ecosystem. Therefore, the organic products will not disguise the distinguishing ecological identity of the Arabian region, which guarantees competitiveness in export (compare for example these products with those manufactured from imported wood or plastics!).

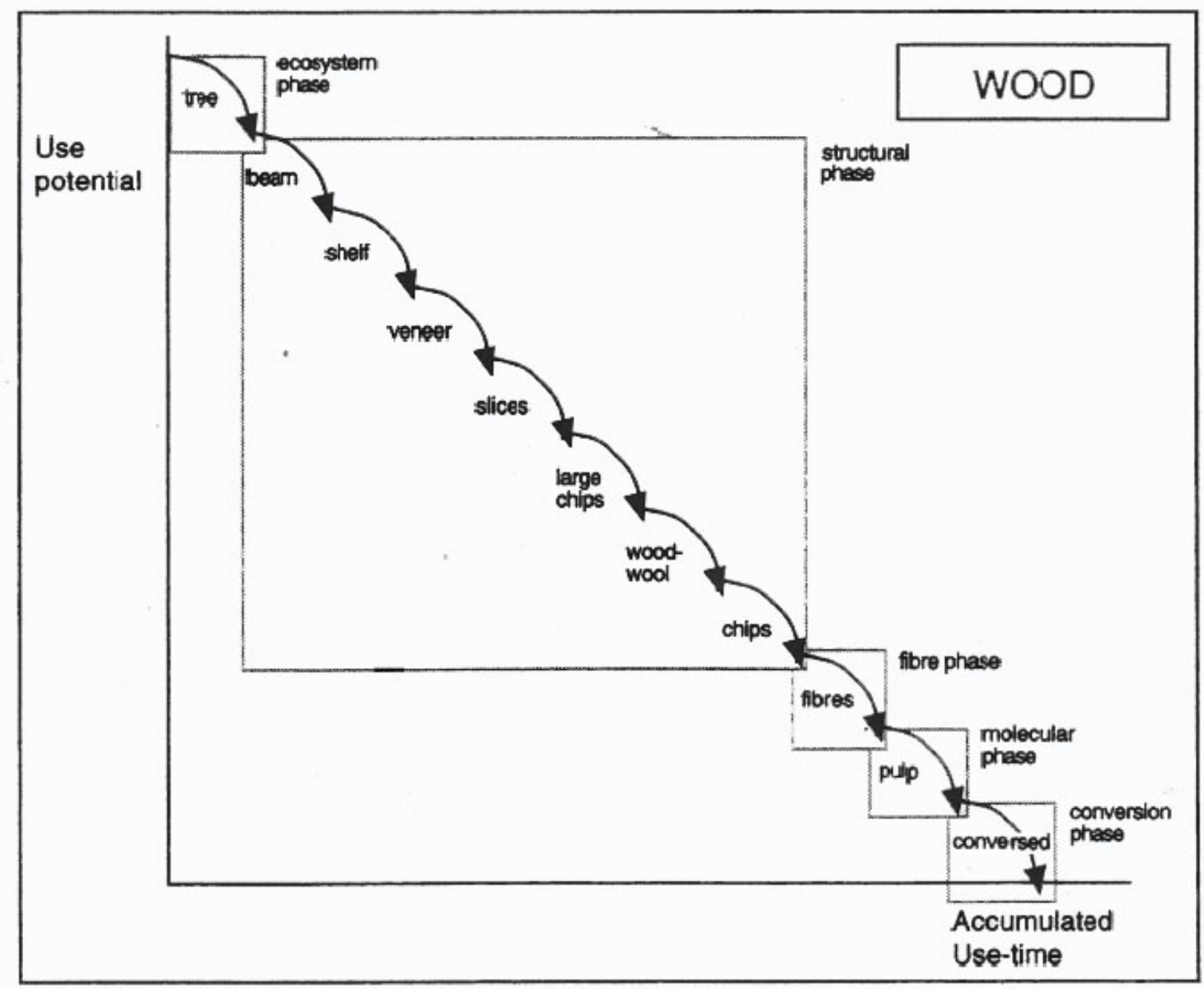

Fig. 17: A cascade of utilization of wood from a life cycle perspective [22].

6. It is expected that the organic products from palm midribs will make use of the chance that the green market offers in the international level. There are strata of environmentally conscious and socially aware consumers, who prefer those organic products, produced in socially just contexts [45]. The success of the trade outlets, such as Fair Trade Net [45], opens the potentiality of manufacture of organic products from palm midribs, as well as products of pruning of fruit trees in general. Besides, the General Preferential System of the EU gives preference for products, produced in the South in an environment friendly way. In addition, the palm midrib products are not in need of a certificate of origin, i.e., that they were manufactured from wood, obtained from sustainably managed forest. I may choose in marketing of these products the slogan: tree-free products [15]. 
7. The organic products from date palm midribs mean that we could realize a qualitative shift in development of uses of palm midribs simply by the innovation of new designs. This means that we could rely on the palm midrib artisans who manufacture crates in the villages in the production of these organic products using their very procedures and traditional tools via their training on the new products. Therefore, the organic products from palm midribs open wide potentiality for the endogenous development of Arabian villages utilizing - and building upon - the locally accumulated traditional knowledge and experience. This in turn gives high guarantee of success of development and makes development more sustainable.

The following organic products have been designed and manufactured from palm midribs:

- $\quad$ Paravane: three pieces (Fig. 18).

- $\quad$ Armchair (Fig. 19).

- Library.

- $\quad$ Chair.

- Partition.

- Basket.

- $\quad$ Photo frame.

- Window unit.

- $\quad$ Sweeper stick.

Ecotourism is one of the most appropriate areas to make use of the organic products from palm midribs and other date palm by-products. 


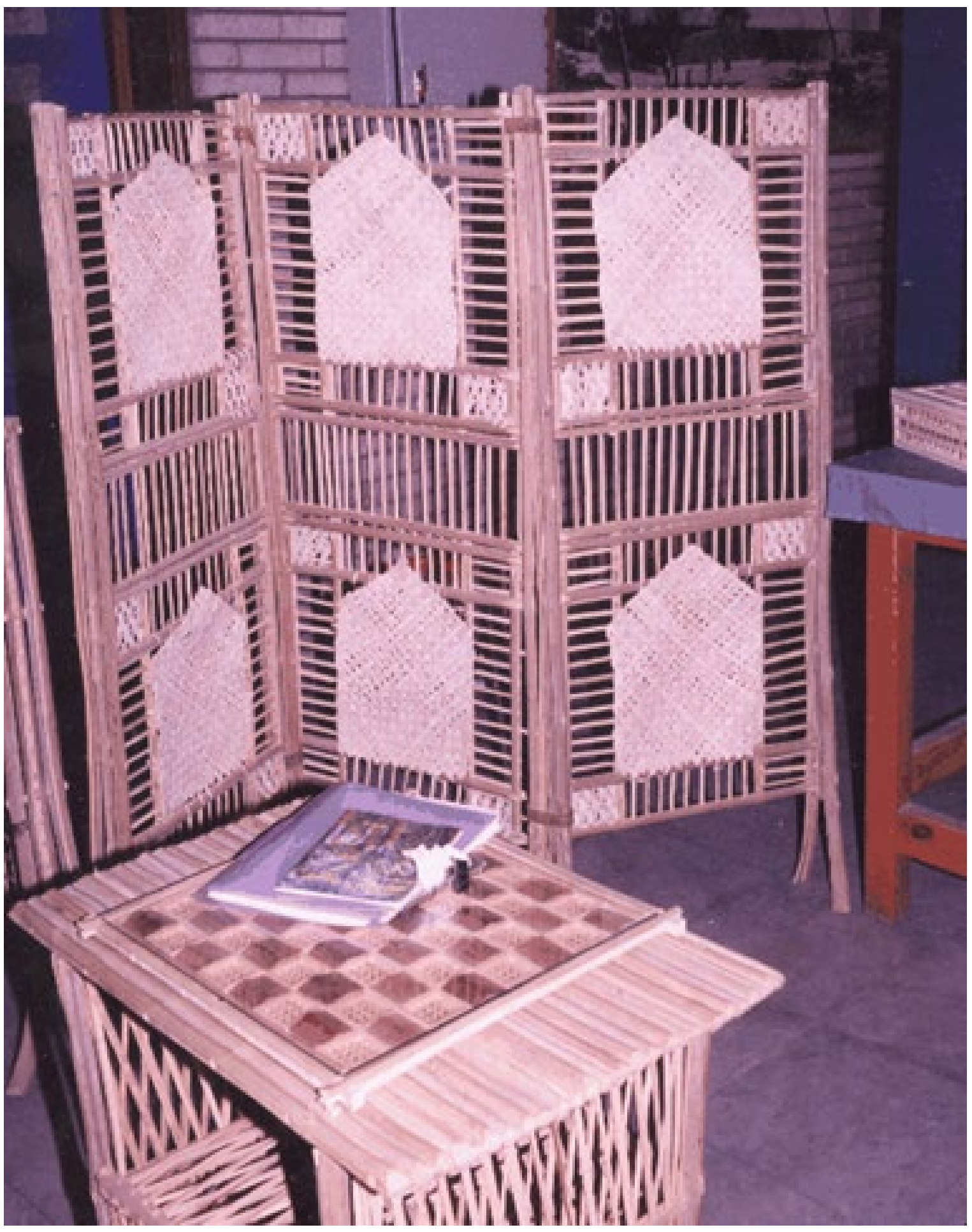

Fig. 18: A paravane: a sample of organic products from palm midribs (Designed by Prof. Dr. Adel Y.M., Ain Shams Univ.). 


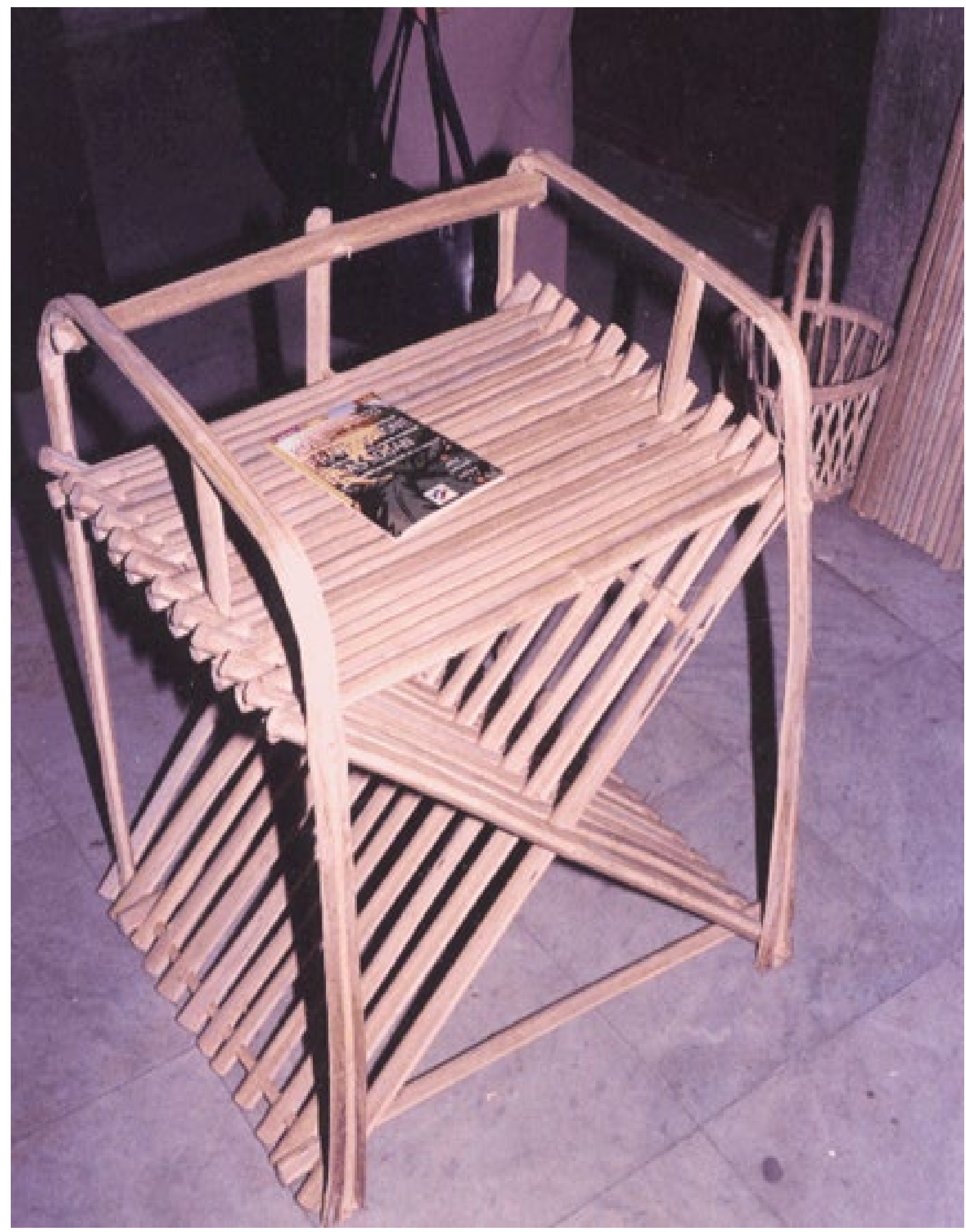

Fig. 19: An armchair: a sample of organic products from palm midribs. 


\subsection{Space Trusses from Palm Midribs}

This research has been conducted within a Ph.D. thesis [6]. The objective of this research consisted in making contribution in the field of low cost roofing using a renewable and abundantly available resource in the Arabian region like the palm midribs. As an approach to the problem space trusses were used as structural elements consisting of members, made from palm midribs and assembled by means of metal joints. During this research it was possible to design, manufacture and test a space truss (Fig. 20), composed of quadratic pyramids. Each is composed of members of equal length, made from palm midribs. The previous prototype with span $3 \times 3 \mathrm{~m}$ was tested under load: measuring the deflections and comparing them with the theoretical values. The results of the research point to the potentiality of use of palm midrib in space trusses as an integrated system to cover the architectural spaces with different spans for permanent and temporal uses, since it is possible to disassemble the structure and reassemble it in new locations. It is possible, as well to use any appropriate locally available material to cover the truss like woven mats from palm leaflets or coir together with using the appropriate protective paints.

\subsection{Use of the Palm Midribs as Structural Elements}

In this thesis, [29] the mechanical properties of the whole palm midrib (tensile, bending and compression) has been determined. Different types of connections for palm midribs have been tested: epoxy, polyester, cement mortar with additives and mechanical connections with steel bolts were investigated. From the results of testing of palm midribs, as well as the joinery exploratory tests, it was found that the truss systems are the most appropriate structural system for use of palm midribs.

After determining the most suitable connection, which was the bolt connection, a series of tests was conducted to determine its behavior and strength. Twenty specimens for single palm midrib bolted connections at different spacing and bolt number were tested. Sixty specimens for double palm midrib bolted connections were tested. It was decided that at least two palm midribs will be used in the truss at different spacing and bolt number.

Three different designs of date palm trusses with span of 3 meters and depth of $1 / 2$ meter have been built and tested. Thus, trusses were built using steel plates and bolts, one using steel rods only and the last two were modification of the traditional design of crates. The results of these tests have shown that the palm midribs can be used as structural elements. A feasibility study has shown that the palm midrib trusses in light structures like canopies and sheds, where steel is dominantly used, could reduce the cost from half to one eighth that of steel.

\subsection{Structures and Sheathing by Palm Midribs}

In a recent work [41], experiments have been performed on the use of palm midribs in the construction of shades, as well as in cladding. The results are encouraging. This opens wide potentialities in use of palm midribs in architectural applications. 


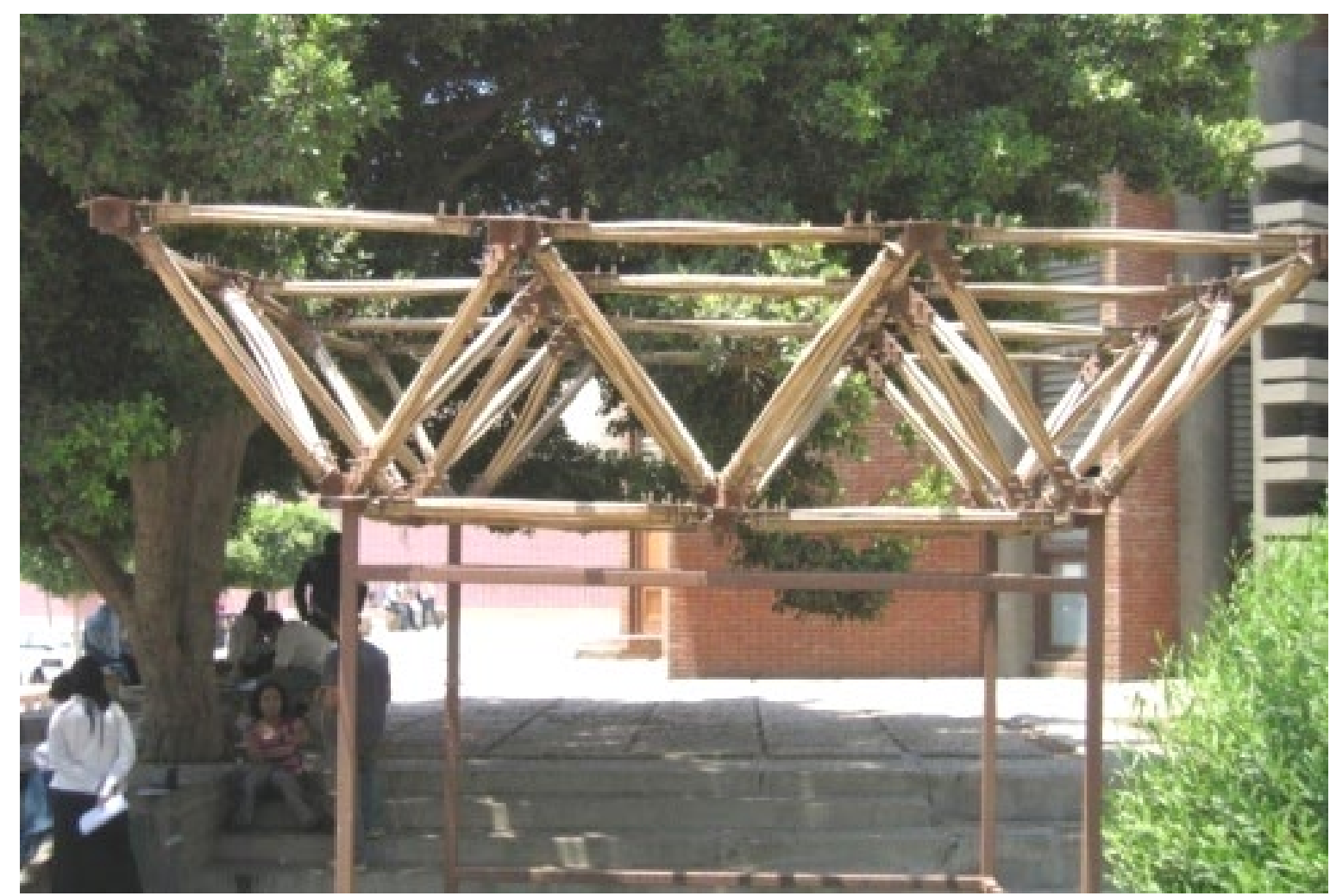

Fig. 20: A prototype of a space truss from palm midribs [16].

\subsection{Particleboards from Palm Midribs}

In October 1993 the factory of the Nasr Company for Particleboards ${ }^{(3)}$ and Resins in El Mansourah has been operated using palm midribs as a base material. An amount of 1.15 ton of palm midribs was used to produce particleboards of size $2240 \times 1220 \times 16 \mathrm{~mm}$. Samples of the factory production were tested according to the Egyptian standard 906/1991 for particleboards. The results of tests showed that the average value of the modulus of rupture (MOR) for these specimens was $20.3 \mathrm{~N} / \mathrm{mm}^{2}$, which satisfies the requirements of the above mentioned standard. In August 1994 the factory of the Modern Arabian Company for Industry of Wood. (MATIN) ${ }^{(4)}$ was operated by about 60 tons of palm midribs brought from Siwa oasis to manufacture 3-layer particleboards with melamine-impregnated paper veneer of dimensions $4.3 \times 1.83 \mathrm{~m}$ and thickness $8 \mathrm{~mm}$, whereby 20 tons were used to produce 100\% palm midribs boards and 40 tons using a blend of palm midribs and casuarina wood (50\% each). The experiment gave positive results, where the properties of the $100 \%$ palm midrib boards were as follows:

- Density: $0.844 \mathrm{gm} / \mathrm{cm}^{3}$.

- Modulus of rupture: $21.9 \mathrm{~N} / \mathrm{mm}^{2}$

- Face strength: $1.07 \mathrm{~N} / \mathrm{mm}^{2}$.

- Internal bond: $0.9 \mathrm{~N} / \mathrm{mm}^{2}$

3 - $\quad$ Report of the El Nasr Company for Particleboard's and Resins, dated 4/12/1993.

4 - $\quad$ Report of the MATIN Company on 24/8/1994. 


\subsection{Medium Density Fiber Boards from the Products of Pruning of Date Palms}

Within the frame work of the project of Care for the Palms in El-Bahriah Oases ${ }^{(5)}$ samples of the products of pruning of palm were collected with ratios, equal to the masses of each of these products with respect to the whole mass of products of pruning.

\begin{tabular}{|l|c|}
\hline \multicolumn{1}{|c|}{ Item } & $\begin{array}{c}\text { Mass, Kg } \\
\text { (air dried) }\end{array}$ \\
\hline Palm midribs & 15 \\
\hline Palm leaflets & 14.6 \\
\hline Spadix stem & 9 \\
\hline Coir & 1.56 \\
\hline Midrib end & 14 \\
\hline Total & $\mathbf{5 4 . 1 6}$ \\
\hline
\end{tabular}

The samples were sent to the laboratories of Naga Hammady Company of Fiber Boards. The results of tests (Appendix 4) are as follows:

\section{Physical and chemical properties}

> Humidity (5.2\%, which falls within the limits of EN 322 standards: 4-11\%);

$>$ Water absorption (12.7\%, which is less than the corresponding value in EN 317: 15);

$>$ Formalin emission (22.54 mg/100 mg, which is less than the corresponding value in EN 120: 30).

\section{Mechanical properties}

$>$ Modulus of rupture $\left(24.4 \mathrm{~N} / \mathrm{mm}^{2}\right.$, which is higher than the corresponding value in EN 310 : 20);

$>$ Modulus of elasticity (2911 N/mm², which is higher than the corresponding value in EN 310: 2200);

$>$ Internal bond $\left(0.9 \mathrm{Nmm}^{2}\right.$, which is much higher than the corresponding value in EN 319: 0.55);

$>$ Surface strength (1.35 N, which is higher than the corresponding value in EN 311: 1.2).

This means that it is possible to manufacture MDF boards from date palm products of pruning satisfying the international standards with respect to their physical, chemical and mechanical properties. This opens the potentiality to establish industrial projects in locations having extensive date palm plantations.

5 - This project has been conducted by the Faculty of Engineering, Ain Shams Univ. in collaboration with the Ministry of Environment during the period from January to October, 2016, the project leader was Prof. Dr. Hamed El Mously. 


\section{Development of Products Using the Uniqueness of the Palm Midribs and Leaflets as a Competitive Advantage}

Four designers joined our team of rediscovery of the date palm by-products. They came with their long history of interaction with consumers from the high and high-middle classes. They put their bet on the uniqueness of the date palms midribs and leaflets: their specific beauty, color and texture. Our interaction with them drove us away from using palm midribs, in a hidden way, in the core of blockboards to expose palm midribs (and leaflets) in quite new products satisfying contemporary needs of high and high-middle classes in Egypt [25]. Thus, a new market has been an opened for the use of palm by-products. Fig. 21 gives examples of these products.

\section{Charcoal from Palm Midribs}

A pyrolysis reactor has been designed and manufactured [10] to produce charcoal in laboratory conditions. This reactor may also serve as an example for productive units to be used in villages. Samples of the Baladi palm midribs have been taken to represent: the top, middle and base of the palm midrib in addition to the bent part (knee) and midrib end left after pruning on palms.

The research results have proven that it is possible to attain FAO standards concerning the calorific value by $86.3 \%$ for the whole Baladi palm midrib. Comparing the palm midrib parts, the FAO standard has been attained by 96\% for the top part; 100\% for the middle part, 84\% for the base part; 96\% for the knee and 74\% for the midrib end. As far as the fixed carbon is concerned, it was possible to attain $102 \%$ of the FAO standard for the whole palm midrib. Comparing the midrib parts the FAO standard has been attained by 117\%, 107\%, 93\%, 97\% and $97 \%$ for the top, middle, base, knee and midrib end respectively. The above-mentioned results show the potentiality of manufacture of charcoal for industrial and agricultural purposes from date palm midribs.

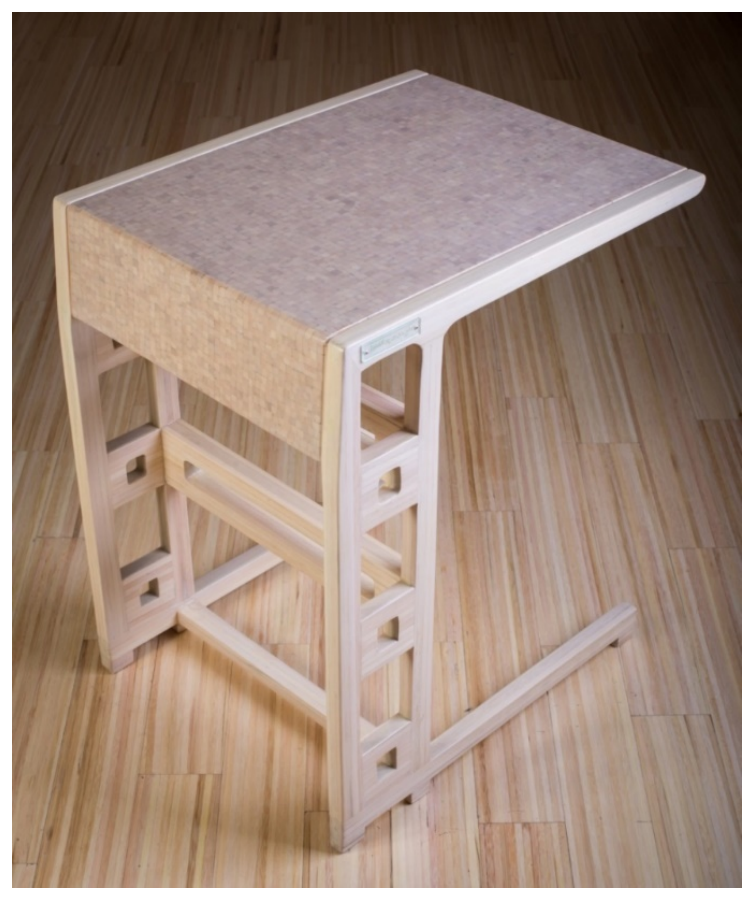

Living room table with a mosaic face

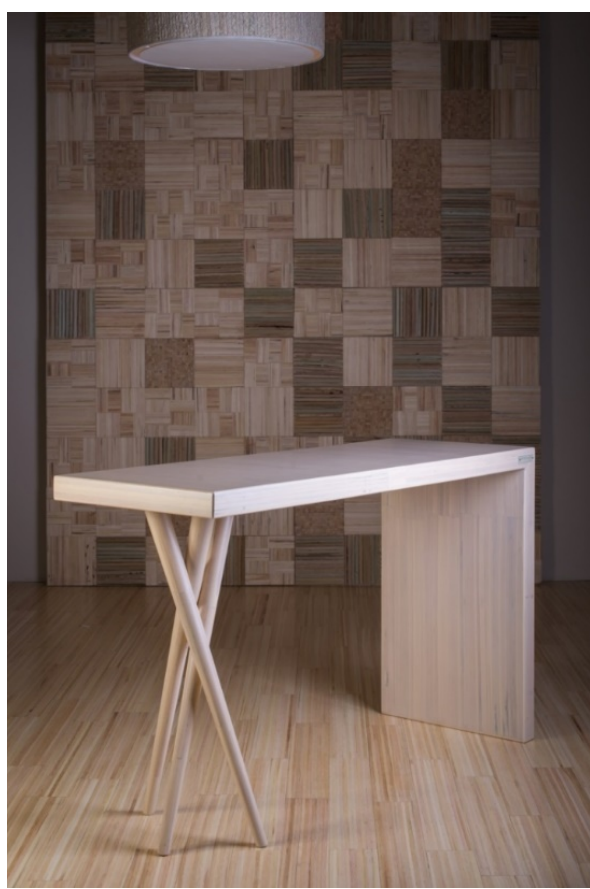

Console Table

Fig. 21: Examples of products, made from date palm midribs. 


\subsection{Impregnation of Palm Midribs to Improve Physical and Mechanical Properties}

Different treatments [21] were applied to improve physical and mechanical properties of palm midribs and namely, treatment with chemicals: water-soluble phenol formaldehyde resin $\left(\mathrm{PF}_{\mathrm{w}}\right)$, alcohol-soluble phenol formaldehyde resin $\left(\mathrm{PF}_{\mathrm{a}}\right)$, melamine formaldehyde resin $(\mathrm{MF})$, linseed oil (LD), methyl methacrylate (MMA), polystyrene (PS) and polyester ( $\mathrm{P}_{\text {est }}$ ), with different concentrations (concentration of treatment material in solution), on weight to weight basis in suitable solvent fluids for the $\mathrm{PF}_{\mathrm{w}}$, the $\mathrm{PF}_{\mathrm{a}}$ and the $\mathrm{MF}: 20 \%, 30 \%, 40 \%, 50 \%$, for the MMA and the LS: $100 \%, 90 \%, 80 \%, 70 \%$, for the $\mathrm{P}_{\text {est }}: 10 \%, 15 \%, 20 \%, 30 \%$ and for the PS: $30 \%, 40 \%$, $50 \%, 60 \%$ ) in a vacuum process with suitable preconditioning before impregnation, curing and post curing after impregnation.

The studied properties included dimensional stability properties: water absorption $\left(\mathrm{WA}_{2,24}\right)$, volumetric swelling coefficient $\left(\mathrm{S}_{2, \mathrm{~m} 24}\right)$, anti-shrink efficiency (ASE $\left.\mathrm{A}_{2, \mathrm{~m} 24}\right)$ after 2 and 24 hours water soak as well as static bending properties: modulus of rupture (MOR) and modulus of elasticity (MOE), shear stress parallel to grain $\left(S_{s}\right)$ and abrasion resistance $\left(A_{r}\right)$.

The results of this study showed significant difference between the behavior of the treated specimens compared with the untreated control specimens. The analysis of the results points to an appropriate value of concentration to achieve the maximum retention levels of impregnation media reaching $25 \%$ with $\mathrm{MF}, \mathrm{LS}, \mathrm{PF}_{\mathrm{w}}$ and $\mathrm{P}_{\mathrm{est}}$, while attaining only $15 \%$ with other polymers.

Most of the treatments showed recognized influence on dimensional stability. For example, the treatment with MF has resulted into decrease of volumetric swelling coefficient from 20.2\% to $1.5 \%$ and from $71.6 \%$ to $9.6 \%$ after 2 and 24 hours water submersion test respectively as compared to the control and water absorption decreased by weight from $37.2 \%$ to $4.9 \%$ and from $165.1 \%$ to $32.5 \%$ after 2 and 24 hours water submersion test respectively as compared to the control.

The impregnation by PS, $\mathrm{P}_{\text {est }}$, LS, and $\mathrm{PF}_{\mathrm{a}}$ increased the MOR values by up to $35 \%$ for both $\mathrm{P}_{\text {est }}$ and PS, 30\% and 23\% for alcohol-soluble phenol formaldehyde and linseed oil respectively. The MOE values increased by up to $45 \%$ for PS, $35 \%$ for polyester and 33\% for alcohol-soluble phenol formaldehyde.

The treatment with LS, MMA, $\mathrm{P}_{\text {est }}$ and MF increased the abrasion resistance by up to $61 \%$ for methyl methacrylate, $43 \%$ for linseed oil, $23 \%$ for polyester and $17 \%$ for melamine formaldehyde, while no treatment improved the shear strength of the DPLM.

Thus, selective treatments could be chosen, for the improvement of physical and mechanical properties of DPLM, based on the needed application and end use.

\subsection{Nano-Particles from Palm Midrib to Reinforce Polymers}

A study [20] was devoted to the effect of nano natural particles on the mechanical properties of epoxy resin. Nano composites were prepared with 1 to $5 \%$ wt. \% of palm midrib nano particles using ultrasonic dispersion method. The results show that increasing palm midrib nano particles content has no positive effect on the ultimate tensile strength, nor the tensile modulus of elasticity and bending strength compared to pure epoxy. However, an increase in impact strength ( 300\%), bending properties and hardness were detected with increasing nano particles content. 


\subsection{Use of Date Palm Midribs in Poultry Feed}

An experiment [34] has been conducted to determine the effects of midrib of the date palm (MDP) when included in corn-soy diets for Gemaza growing chicks on growth performance, carcass characteristics and economic efficiency. A total number of 150 one - day old Gemaza chicks (local breed) were distributed equitably into 5 dietary treatments in 3 replicates of 10 birds each. Five experimental diets in each period (starting, growing and finishing) were formulated, in which control diet was $10 \%$ wheat bran, in the other MDP were incorporated at levels $2.5,5,7.5$ and $10 \%$ to obtain four experimental diets $\left(\mathrm{T}_{1}-\mathrm{T}_{4}\right)$ respectively.

The results indicated that:

1 - There were no significant differences in body weight, body weight gain and feed conversion between chicks fed by control diets and other treatments in different growth periods.

2 - Chicks fed by control diets or diets containing $10 \%$ MDP $\left(\mathrm{T}_{4}\right)$ significantly consumed less feed than the other dietary treatments during starter (0-6 wks) and whole experimental periods (0-12 wks).

3 - $\quad$ Carcass characteristics parameters (Dressing Giblers, Breast, thight, Drumstic wing and wing \%) showed insignificant figures when chicks fed by diets containing MDP compared to those fed by control diets.

4 - $\quad$ Tibia characteristics, it is worth to note that birds fed by different levels of MDP $\left(T_{1}-T_{4}\right)$ reflected the lowest figures compared with control diets.

5 - Economic evaluation, the best economical efficiency value was demonstrated when chicks were fed by $10 \%$ MDP and the value was $67 \%$ more when compared with that of chicks fed control diets.

\subsection{Use of Date Palm Midribs in Livestock Feed}

This study [30] has been carried out at Regional Center Food and Feed and El-Gemmaiza experimental Station, Animal Production Research Institute, Ministry of Agriculture, Egypt. The aim of this work was to improve the nutritive values of the poor quality roughages by biological treatments with oyster mushroom and to study their effects on feed intake, digestibility, nutritive values, and performance of growing lamb. The present work was conducted to study the effect of biological treatments of palm fronds grinded (PFG) by Fungi (Pleurotus Ostreatus) in sheep ration. Twenty four Rahmani lambs with average about $22.50 \mathrm{~kg}$ live body weight were randomly chosen and divided into four groups (6 in each) to evaluate the experimental rations containing PFG. The treatments were: Control (C) $60 \%$ of allowances from concentrate feed mixture (CFM) of NRC (1986) requirements + palm fronds grinded (PGF) ad lib. Ration 1-60\% of allowances CFM + palm fronds grinded treated with (Pleurotus Ostreatus) (PGFT) ad lib. Ration $2-50 \%$ of allowances CFM + palm fronds grinded treated with (Pleurotus Ostreatus) (PGFT) ad lib. Ration $3-40 \%$ of allowances CFM + palm fronds grinded treated with (Pleurotus Ostreatus) (PGFT) ad lib. Four digestibility trials were performed to determine the nutritive value of the experimental rations. The main results were as following: $1-$ The DM intake was insignificantly increased with increasing PFGT ration; 2 - The daily body gain $(\mathrm{kg})$ were $0.141,0.149,0.145$ and 0.137 and the feed conversion were 10.23, 9.72, 10.11 and 10.58 ( $\mathrm{kg} \mathrm{DM} / \mathrm{kg}$ gain) for rations $\mathrm{C}, \mathrm{T} 1, \mathrm{~T} 2$ and T3 respectively, which were nearly similar except for ration T3; 3 - The DM and OM digestibilities for ration T1 were significantly $(\mathrm{P} \leq 0.05)$ higher 
than ration T3. The CP digestibility for ration T3 was significantly lower than those of rations $\mathrm{C}$ and T1, which it was not significant with T2 for the other treatments; 4 - The CF digestibility for ration $\mathrm{T} 2$ and $\mathrm{T} 3$ were significantly $(\mathrm{P} \leq 0.05)$ higher than ration $\mathrm{C}$, while digestibility of NFE for ration $\mathrm{C}$, $\mathrm{T} 1$ and $\mathrm{T} 2$ were significantly $(\mathrm{P} \leq 0.05)$ higher than those of ration $\mathrm{T} 3$; 5 - The TDN of ration $\mathrm{C}$ and $\mathrm{T} 1$ were significantly $(\mathrm{P} \leq 0.05)$ higher than other treatments, while DCP of ration $\mathrm{T} 3$ was significantly lower than those of rations $\mathrm{C}$ and $\mathrm{T} 1$, but differences between $\mathrm{T} 2$ and T3 in DCP digestibility were not significant. Data also revealed that, rations containing PFG with or without Fungi treatment appeared to have higher net revenue and economical efficiency. It could be concluded that palm fronds grinded by Fungi treatment (Pleurotus Ostreatus) is a good quality feed in sheep ration up to $60 \%$.

\subsection{Palm Secondary Products as a Source of Organic Material for Compost Production}

The Bahariah oases are located in the western desert of Egypt. The number of palms in these oases is estimated by 1.3 million palms producing $~ 70$ thousand tons (air dry weight) of palm secondary products $^{(6)}$ within this project an experiment has been conducted to use the palm secondary products (PSP) in the manufacture of compost in Mandisha village.

The locally available poultry manure being a residue of the local poultry industry was used as a compost activator. Thus 3 tons of compost has been produced from $\sim 8$ tons of PSP. The physicochemical analysis of Bahariah oasis compost in as follows [12]:

\begin{tabular}{|l|c|}
\hline \multicolumn{1}{|c|}{ Parameter } & Bahariah oases compost \\
\hline $\mathrm{pH}(1: 10)$ & 7.84 \\
\hline EC $\left(\mathrm{dsm}^{-1}\right)(1: 10)$ & 4.61 \\
\hline Organic C (\%) & 26.54 \\
\hline Organic matter \% & 45.66 \\
\hline Nitrogen (\%) & 1.12 \\
\hline C/N ratio & $21.75: 1$ \\
\hline Phosphorous (\%) & 0.01 \\
\hline Potassium (\%) & 0.91 \\
\hline Bulls density (9 $\left.\mathrm{cm}^{-3}\right)$ & 0.678 \\
\hline Moisture content $(\%)$ & 27 \\
\hline
\end{tabular}

6 - The project of Care of Date Palms in El Bahariah oases, executed by the Faculty of Engineering, Ain Shams University in the period from January to July, 2016. The project leader is Prof. Dr. Hamed El Mously. 
This opens a great developmental potentiality to use the date palm secondary products being treated as waste at the present time and thus representing a direct cause of fire in the palm gardens, in the production of compost urgently needed to reclaim desert areas in the oases.

\section{Machines for the Conversion of Palm Midribs Into Uniform Cross-sections}

One of the big challenges we met in our way to use palm midribs in different industrial applications was how to transform the palm midrib irregular cross-section (Fig. 5) into a regular cross-section (e.g. square, rectangular, circular or triangular, etc.). This was a precondition to obtain from palm midribs strips of regular cross-section (Fig. 22) to be further used in making boards of regular thickness (Fig. 23) or blocks of regular cross-section (Fig. 24). Thus, in embarking on designing machines for the conversion of palm midribs into pieces of regular cross-sections we took into consideration that the context, where these machines may operate may widely vary: from a small modern factory producing standard products from palm midribs, to small workshops producing palm midrib strips on a subcontracting basis to the pattern of home production in the villages with large palm plantations producing only palm midrib strips. These stripping machines could be classified according to the principle of operation in to two main categories:

I - $\quad$ Stripping machines producing palm midrib strips by cutting using disc saws; (Fig. 25).

II - $\quad$ Stripping machines producing palm strips by skinning or pealing (Fig. 26).

The first family of machines using the principle of cutting could be divided into two types.

\section{Simplex stripping machine}

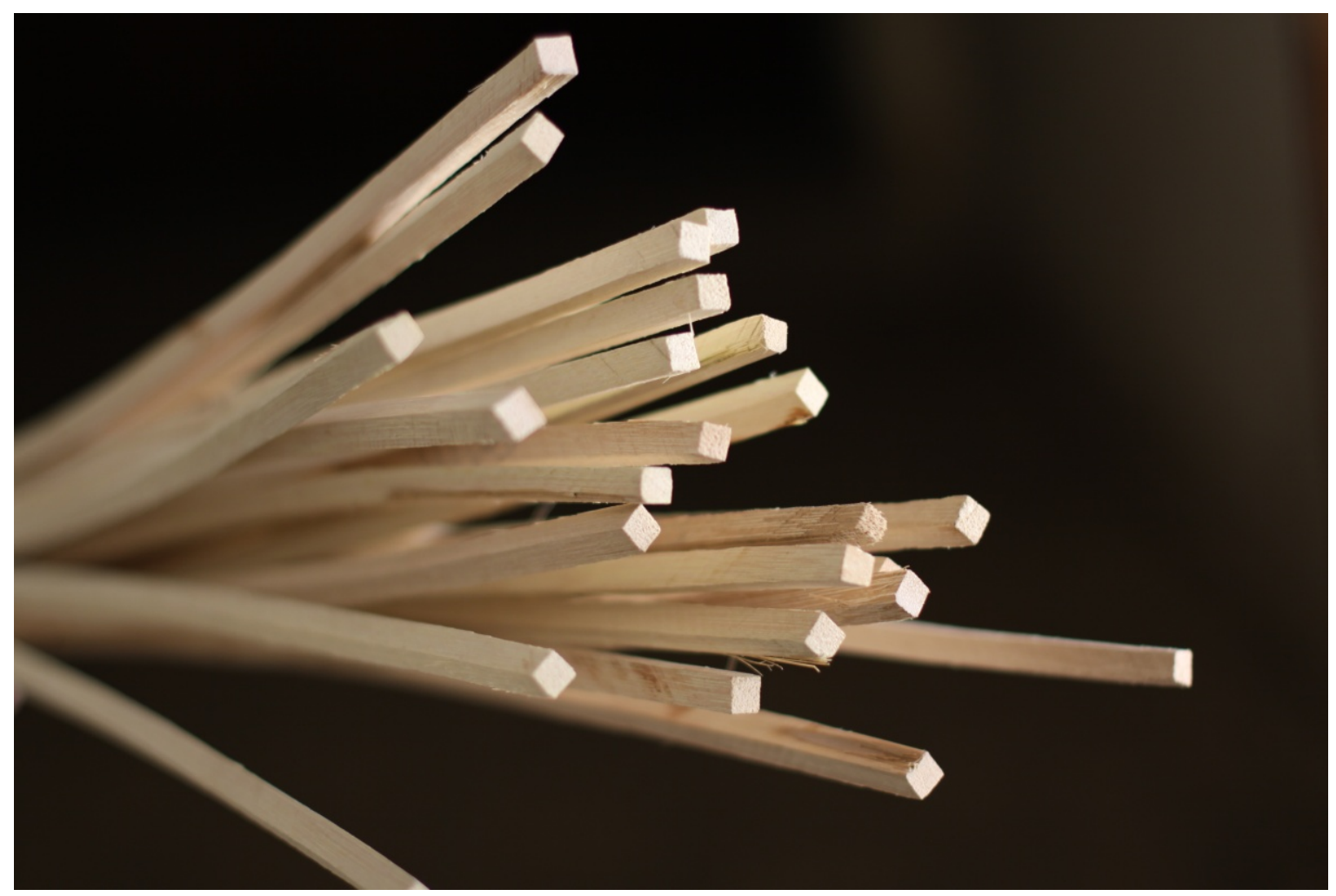

Fig. 22: Strips from palm midribs. 


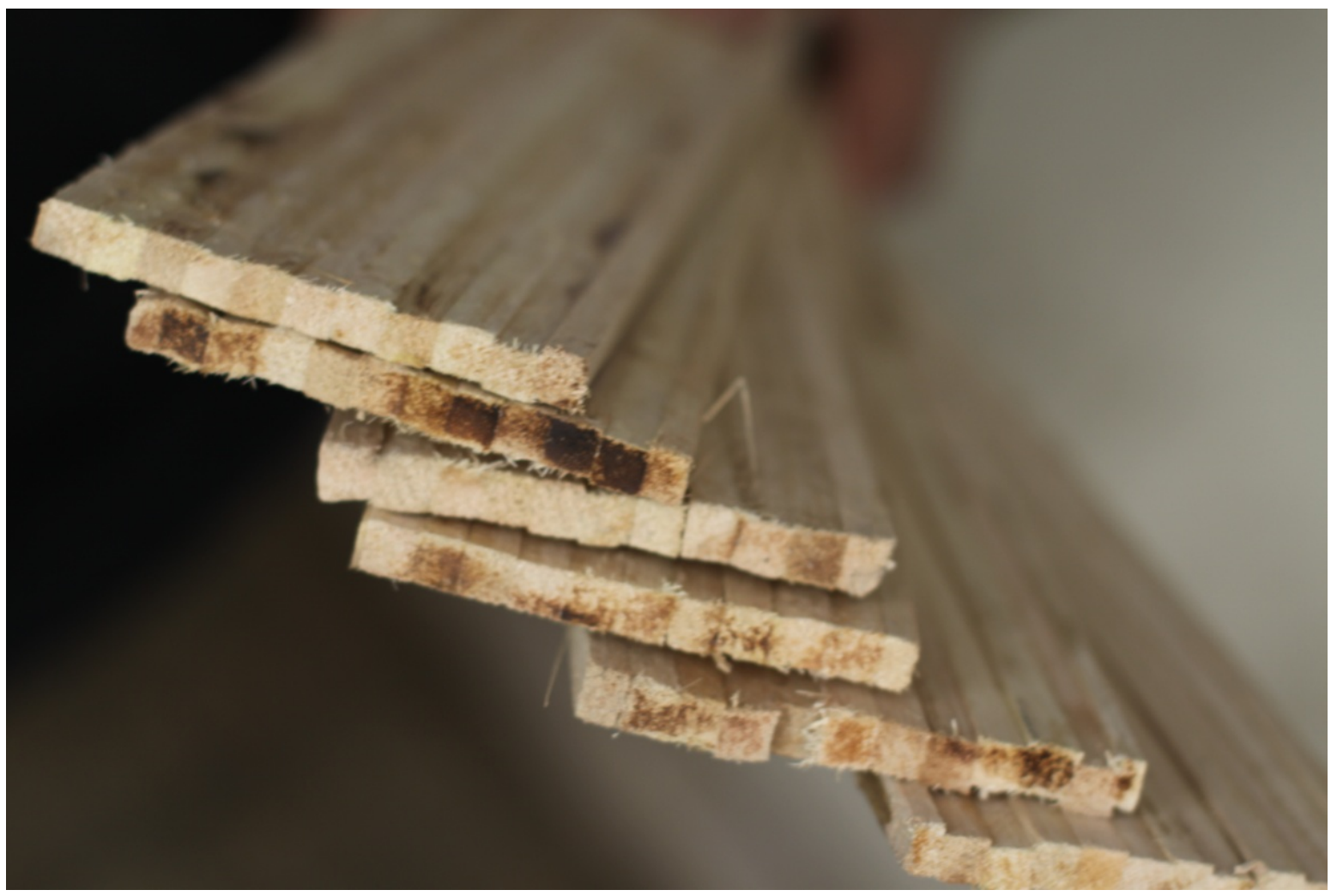

Fig. 23: Boards from palm midribs.

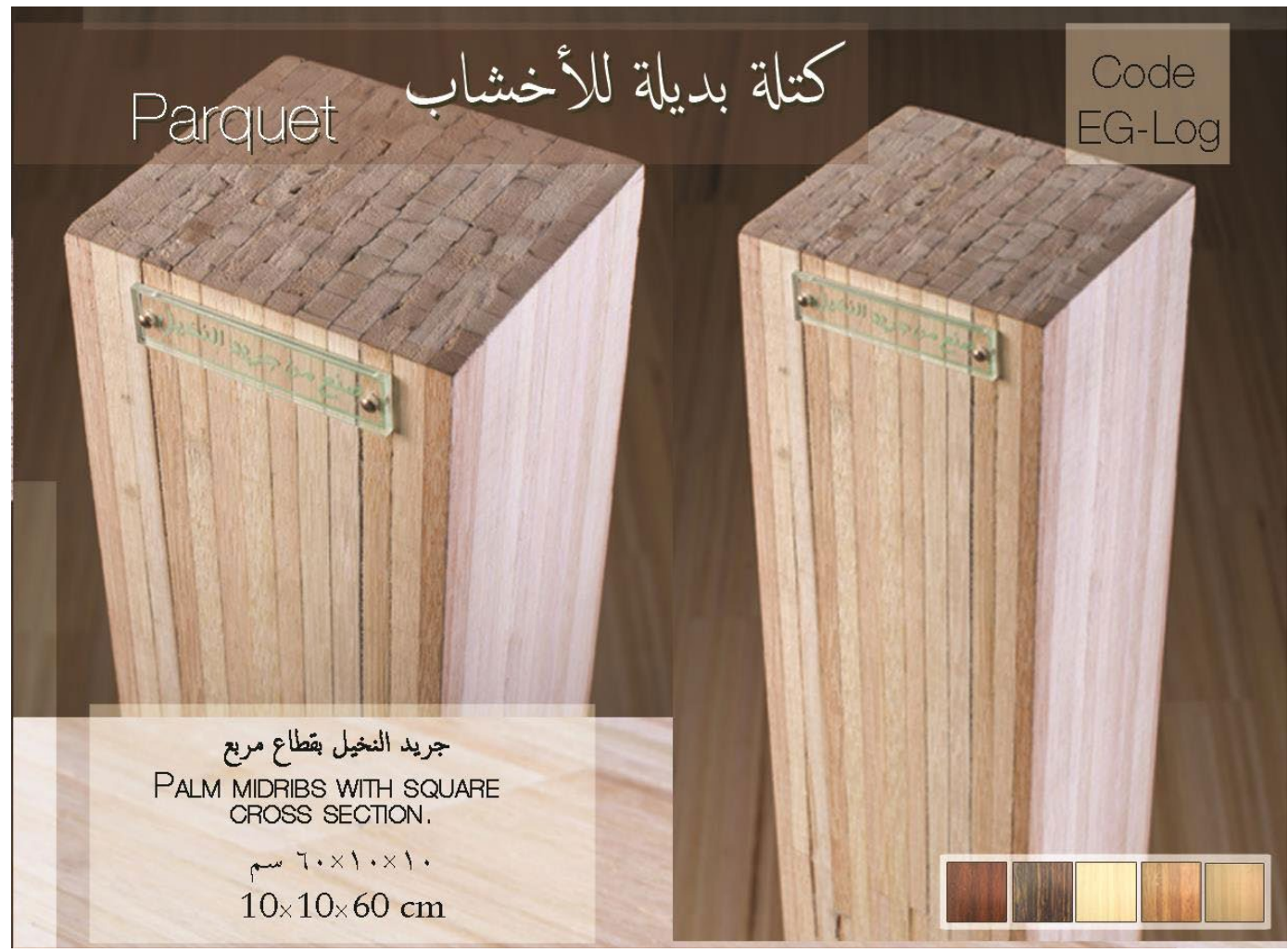

Fig. 24: A beam from palm midribs. 

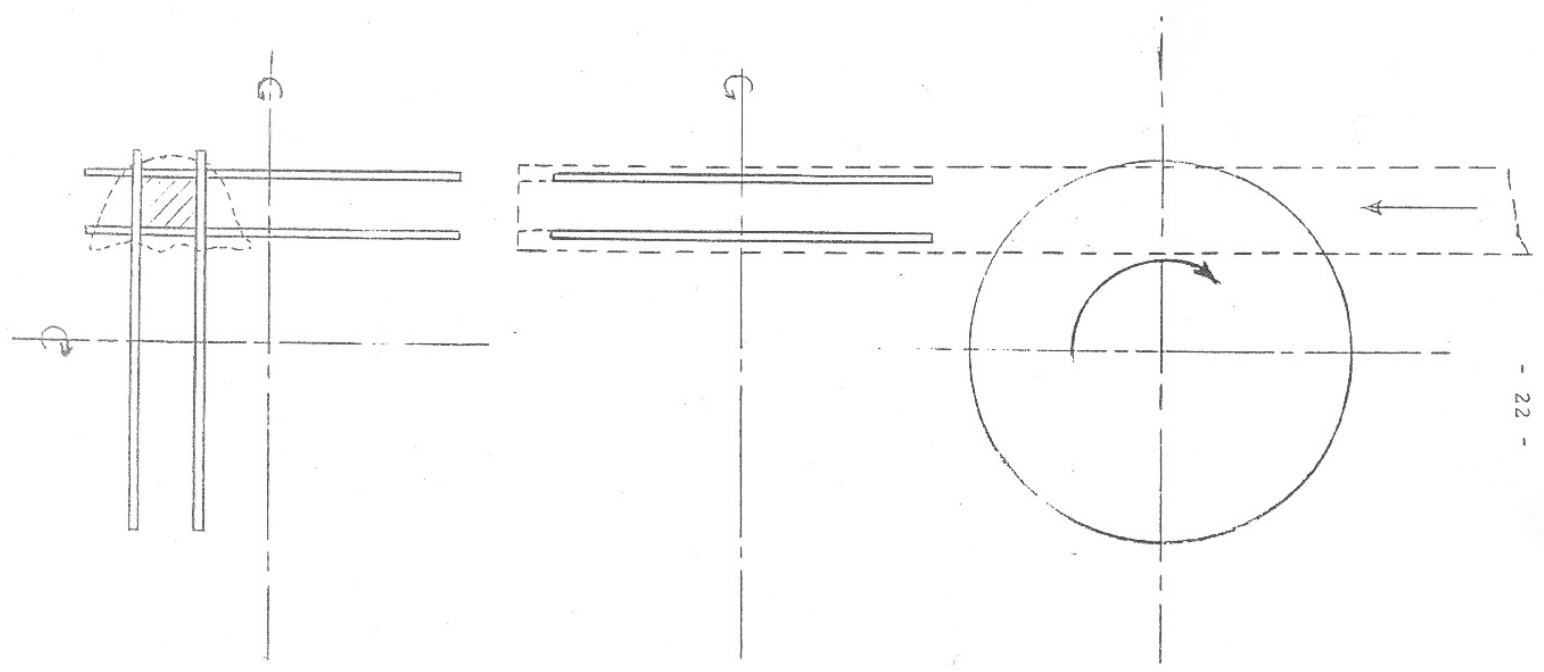

Fig. 25: A diagrammatic sketch showing the main principle of operation of the stripping machine producing palm midribs strips by cutting.

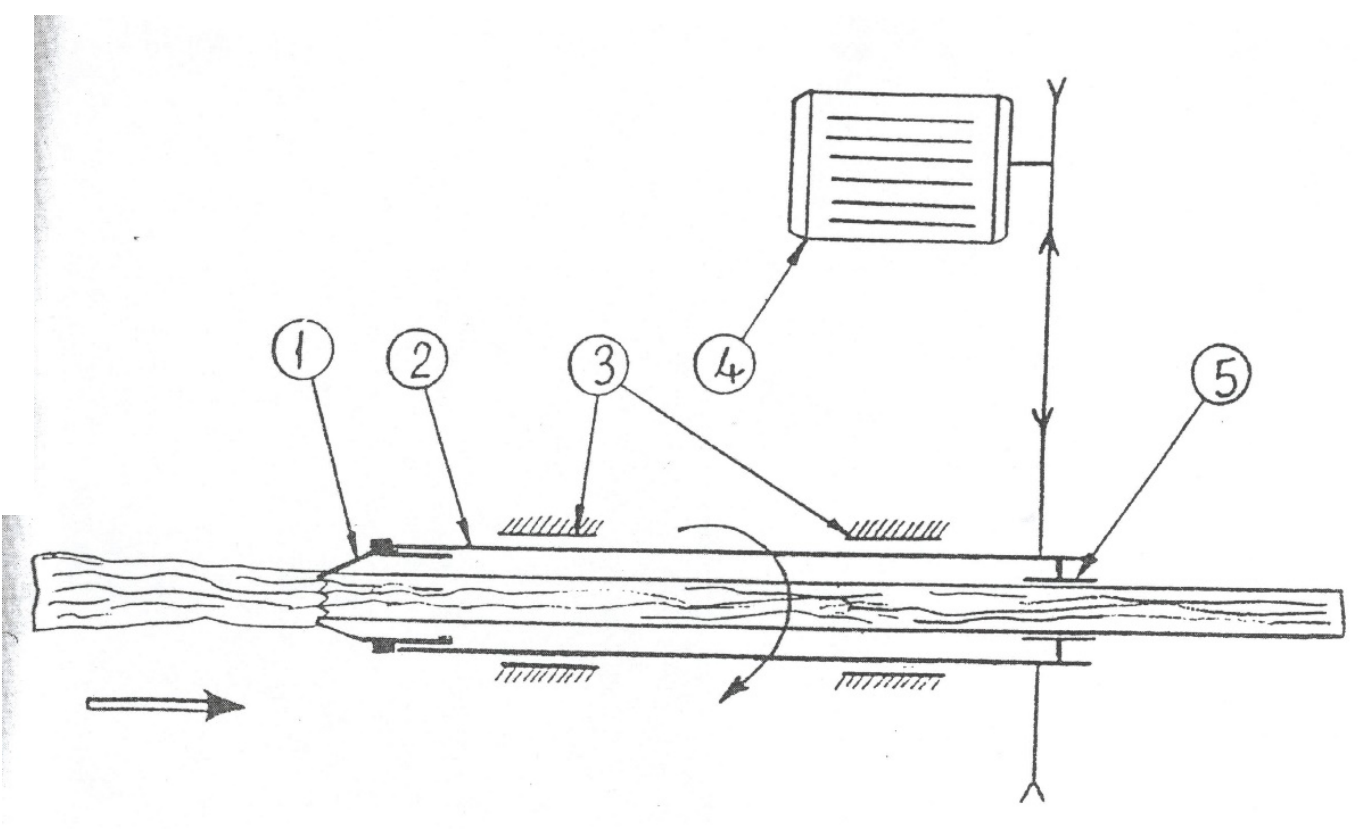

Fig. 26: A diagrammatic sketch of the machine for the producing of palm midribs strips by skinning preparation of DPLM for cutting into strips:

1. collet cutter, 2 . hollow spindle, 3 . bearings, 4 . motor, 5 . a guide collet.

This machine includes only one cutting station operating with a pair of carbide-tipped disc saws. Thus, the palm midrib strip could be produced: either using two machines operating in series, or using one machine and readjusting the distance between the disc saws: first to get the width and second to get the height of the strip from the raw palm midrib piece. 


\section{Doublex stripping machine.}

In this machine two cutting stations are positioned successively each having 2 disc saws set at the required space corresponding to the strip width and height. The feeding of the palm midrib piece is affected mechanically. Thus, the doublex stripping machine is a semiautomatic machine operated by one worker and of high rate of production.

The second family of machines using the principle of skinning rely on the use of collet cutters, designed to produce the whole section at once of the strip. These machines could be divided into the following models:

$>$ Pull-type skinning machine

This machine is designed to convert the whole palm midrib into one strip of the required cross-section.

$>$ Push type skinning machine

This machine is designed for the skinning of the palm midrib piece to the required crosssection.

Lever type skinning machine

This machine is designed for the manual operation using a lever. Skinning is performed: either by using a collet-form tool or meshing blades cutter. Different models of the skinning machines have been later designed and tested.

\section{Future prospects of use of date palm by-products for sustainable development}

\section{Date palm by-products as a substitute for wood}

Egypt has imported in 2014 wood [16] and wood products for $\sim 2$ billion US \$. This represented a big burden on the country's balance of payment. Taking into consideration the influence of inflation in wood prices in future, as well as the expected increase of population this estimate will reach 177 billion US \$ in 2050, which represents an unallowable burden on future generations [32] ! Besides, according to a forecast (Table 6) the World will face a huge shortage in wood supply amounting to a 484 million $\mathrm{m}^{3}$ in 2020 . 
Table 6: Forecast of wood timber supply: 2010-2020

\begin{tabular}{|lccc|}
\hline Region & 1996 & 2010 & 2020 \\
\hline Oceana (New Zealand \& Australia) & 42 & 58 & 74 \\
\hline South America & 130 & 158 & 190 \\
\hline North and Central America & 600 & 503 & 539 \\
\hline Europe and the Baltics & 282 & 330 & 355 \\
\hline Asia & 252 & 217 & 288 \\
\hline Africa & 67 & 66 & 70 \\
\hline Russia & 67 & 130 & 160 \\
\hline Total supply & 1,439 & 1,461 & 1,616 \\
\hline Forecast demand & & 1,801 & 2,100 \\
\hline Forecast shorttall & & 340 & 484 \\
\hline
\end{tabular}

Source: International Forestry Report

Drawing a comparison between the date palm, short rotation forests and Aspen forest we come to the following conclusion:

$>$ The products of pruning of the date palm $\cong 15.9$ ton (oven dry) per hectare.

$>$ The annual rate of yield of short rotation forests $=9.0$ ton (oven dry) per hectare; [44] .

$>$ The annual rate of yield of traditional Aspens forest $=2.5$ ton (oven dry) per hectare [49]

This means that quantitatively speaking the products of pruning of date palms are competitive with respect to wood.

In March 2013 EU has issued a law prohibiting the importation of any furniture or other timber product made from illegally logged timber to the EU market. This law, [31] together with the increasing concern for the preservation of natural forests world-wide provide a strong comparative advantage - and create a market niche - for tree-free products, made from palm midribs.

This means that the date may be looked to in future as an additional crop of the date palm plantations producing tree-free products!

In other terms, the date palms may be cultivated in future to obtain two crops: date crop and products of pruning as a lignocellulosic crop and a substitute for imported wood.

\section{Palm Fibers for Pulp and Paper}

The total world paper consumption increased from 324 million tons in 2002 to 389 million tons in 2008 and is expected to grow steadily in the next decade reaching above 500 million tons [42]. The main source of raw material for pulp and paper is soft wood and hard wood species, which are obtained from forests. 
Thus, the preservation of forests necessitates the search for other alternatives as a source for pulp. The palm by-products could be an alternative. For example, the cellulose content \% has been evaluated [37] for the Siwi species date palm and found as follows:

\begin{tabular}{|c|c|c|c|c|}
\hline Palm & Spadix & Palm & Palm & Palm \\
\hline Midrib & Stem & Leaflet & Midrib end & Coir \\
\hline $43.34 \%$ & 46.65 & 38.71 & 37.72 & $51 .-52$ \\
\hline
\end{tabular}

This gives a very promising indicator of the potentiality of use of palm by-products as a source of pulp.

In one of the researches [38] it was possible to perform pulping of palm midrib with a yield of $45 \%(\mathrm{w} / \mathrm{w})$. The physical properties of the prepared hand sheets were very similar to those displayed by other papers made of common lignocelluloses fibers. Pulps from the date palm midrib gave paper sheets with good properties without the need of refining operations. This feature can be considered as a serious advantage when looking to alternative sources of fibers for paper making. Thus, palm midribs could be considered a potential source of fibers for paper making applications. These results are confirmed by another research [36] concluding that the fiber of date palm is close to that of hardwoods with a yield of pulp (41-45\%). The palm leaflets gave a low yield of (28.3\%) and both pulps were bleached to good brightness and strength properties in between those for spruce and aspen.

\section{Palm Fibers for the Reinforcement of Polymer Composites}

Polymers have become attractive materials for various applications due to several attractive properties, including light weight, ease of processing and cost effectiveness. Hence, attempts have been significantly made to utilize polymers in different industrial applications, using various kinds of reinforcements including fibers to increase their physical and mechanical properties.

The availability of natural fibers and the ease of manufacturing have tempted researchers to study the feasibility of their application as reinforcement. Compared with the traditional reinforcements, for example, glass and carbon fibers, lignocellulosic fibers impart the composite certain benefits, such as law density and result in highly reduced wear of processing equipment. Moreover, they are readily available from natural sources at a low price [48]. A number of major industries, such as the automotive, construction and packaging industries have shown a considerable interest in the progress of new natural fiber reinforced materials [43].

In search for new fiber types a pioneering research has been conducted to develop combined multi criteria evaluation stage technique (CMCEST) to evaluate six different natural types of fibers: coir, date palm, jute, hemp, kenaf and oil palm. Utilizing the proposed technique, the date palm fibers were found to be quite promising due to beneficial characteristics revealed in the combined triple evaluation criterion, which provide a reasonable cheap and eco-friendly alternative material suitable for different applications [13].

Regarding the low compatibility of palm fibers with relatively hydrophobic polymer matrices, a research has been conducted to improve the interface and interphase interactions between date palm fibers and polyester. The combination of alkaline and silane coupling agent resulted in 
substantial adhesion improvement [13]. The results of this research support the use of palm fibers in composites.

The use of recycled plastics in the manufacture of natural fibers-polymer composites has high future prospects. In a pioneering work [19] date palm leaf fibers have been used to enhance the mechanical properties of recycled poly (ethylene terephthalete) ( $\mathrm{PET}_{\mathrm{r}}$ ). the addition of these fibers has enhanced both the tensile and flexural strength. In addition, the impact strength was increase with higher fiber loading [19].

The increasing environmental concerns with the use of petroleum-based plastics at the disposal stage (e.g. the environmental pollution resulting from the burning of plastics or the environmental troubles associated with landfilling) point to the high future potentiality of use of biodegradable polymers, reinforced by fibers obtained from palm by-products.

\section{Palm By-products as a Material Base for Bioeconomy}

\subsection{Date Waste}

Date palm fruit, one of the most nutritive and comprehensive fruits in terms of health benefits is an ideal substrate for deriving a range of value added products in food and nutraceutical industries in the coming future employing bioprocessing technologies, which have immense scope for application in the valorization of date fruit by-products and wastes [17]. The amount of annual date waste for Egypt, Saudi Arabia, Iran, UAE and Algeria amount to 840300 metric tons $^{(7)}$. These huge quantities, annually available sustainably, provide ample scope for the emergence of new bioindustries and bioentrepreneurs in the date growing countries towards total utilization of the date palm in addition to efficient and effective date palm fruit waste management. There are high prospects, of valorization of these date fruit processing by-products and wastes employing fermentation and enzyme processing technologies towards total utilization of this valuable commodity for the production of biofuels, biopolymers biosurfactants, organic acids, antibiotics, industrial enzymes and other possible industrial chemicals [17].

The production of ethanol from dates will be an attractive option in future. Ethanol is used in a wide range of industrial products (cosmetics, perfumes, pharmaceuticals, solvents, detergents, disinfectants and organic acids). Citric acid is widely used in the food, beverage, chemical pharmaceutical and other industries. $\alpha$-Amylase is used in ethanol production to break starches in grains into fermentable sugars. In one of the researches [11] ethanol, citric acid and $\alpha$-amylase have been successfully produced from date waste. In another research [9], spoilage date palm fruits have been successfully used to produce: acetone - butanol - ethanol. This reveals a great potential fur furthering industrialized production of these chemicals.

\subsection{Lignocellulosic Biomass}

The palm lignocellulosic by-products include the palm midribs, leaflets, spadix stems, palm midrib ends, coir and palm trunk after the end of life. These represent renewable materials sustainably available in the locations of palm plantations. According to [42] and [13] the yearly amounts of products of pruning in Saudi Arabia is about 1 million metric tons. These residues contain cellulose, hemicellulose and lignin by ratios varying from 43.3 : 15.5 : 5.6 , 46.7 : 16.4 : $7.6,38.7: 7.9: 11.3,37.7: 14.5: 13.4$ and $51.5: 12: 16.3$ for the palm midrib, spadix stem, leaflets, midrib end and coir for the Siwi palms [26]. There is a growing interest in converting the lignocellulosic mass to respectively valuable green fuels and high value added chemicals.

7 - This estimation is based on the figures of annual date production in [17 and 11]. 
Various pretreatment processes are available to fractionate, solubilize, hydrolyse and separate cellulose, hemicellulose and lignin [40].

\subsubsection{Cellulose}

Cellulose has been widely used as a main source of paper since the beginning [14]. At the present time bioethanol is focused as a cellulose based biofuel. Bioethanol is the most widely used liquid biofuel. In 2008 worldwide production of bioethanol was over 41 billion liters. In addition, biohydrogen could be produced from cellulose. The biohydrogen could be used in chemical and oil industries. It is expected that the demand for hydrogen fuel for bitumen upgrading will increase (the capacity of upgrading bitumen is expected to be about 2045 thousand barrels in 2020). The cellulose derivatives are of great significance as well. Methyl cellulose is used on a thickener and emulsifier in various food and cosmetic products. It has medical applications to treat constipation, diverticulosis, hemorrhoids, irritable bowel syndrome, as well as to treat diarrhea. It is also used as a performance additive in construction materials. It can be used as a mild glue. It is also used in the manufacture of capsules in nutritional supplements. The ethyl cellulose-a cellulose derivative-is mainly used as a thin film coating material, as well as a food additive as an emulsifier. The cellulose acetate - another cellulose derivative - is used as a film base in photography, as a component in some adhesives, and a frame material for eyeglasses. It is also used as a synthetic fiber and in the manufacture of cigarette filters and playing cards. Nitrocellulose is used as a propellant or low - order explosive. Nitrocellulose, plasticized by camphor was used by Kodak and other suppliers from the late 1880 as a film base in photograph, $\mathrm{x}$-ray films and motion picture films. Carboxymethyl cellulose is often used as its sodium salt, sodium carboxymethyl cellulose.

The hydroxypropyl cellulose is used to prepare artificial tears and to treat medical conditions characterized by insufficient tear production. Nanocellulose is a new field of research at the moment. It can be used in paper and paper board productions, in food as a low calorie replacement, in medical and pharmaceutical uses in making tobacco filter additive, in battery separators, in loudspeaker membranes, in tissue, non-woven products or absorbent structures,. It is often used as antimicrobial films, in coil recovery applications and in drilling mud [14].

\subsubsection{Hemicellulose}

Different biochemicals can be produced from hemicelluloses. Bioethanol as a fuel can be produced by fermentation of hemicellulose hydrolysates, as well as xglitol having important applications in pharmaceuticals and food industries due to high sweetening properties and also as sugar substitute for diabetics. Other value added products can be produced from hemicellulose hydrolysates, such as butanediol, a valuable chemical feedstock, because of its application as a solvent, liquid fuel, and as a, precursor for many synthetic polymers and resins.

Ferulic and vanillin can also be produced. There are reports about antiradical, oxidase in hibitory, antiinflammatory, antimicrobial, anticancer activities of ferulic acid and its derivatives. Vanillin is, industrially used as fragrance in food preparation, intermediate in the production of herbicides antifoaming agents or drugs, ingredient of house hold products, such as air fresheners and floor polishes and also as food preservative. Lactic acid, furfural, butanol, biohydrogen, chitosan and xylo-oligosaccharides can be produced. Lactic acid is widely used in food, pharmaceutical and textile industries. It is also used as a source of lactic acid polymers, which are being used as biodegradable plastics. Furfural is used for the production of a wide spectrum of important non-petroleum derived chemicals. It is mainly used for the production of resin. Butanol offers a number of advantages and can help accelerate biofuel adoption in countries 
around the world. Its primary use is as an industrial solvent in products such as lacquers and enamels. Biohydrogen production may provide a renewable more sustainable alternative. Chitosan has found numerous applications in food, cosmetics and pharmaceutical industriesXylo-oligosaccharides are finding applications in fields related to the food and pharmaceutical industries [40].

\subsubsection{Lignin}

Lignin (e.g. lignosulfonates) is used to make vanillin (a flavoring for food, ice cream and bakery goods). It is also used for mud viscosity control during deep oil well drilling Lignosulfonates also help to control the viscosities of particle suspensions in making bricks, tiles, gypsum boards, in grinding and polishing, in spraying pesticides, in distributing carbon black during rubber master batching, and in textile dying. Lignin finds outlets in preparing isolation boards, linoleum and floor tile pastes, animal feed pellets, coal dust briquettes and foundry and casting form. It is also used for dust control in ceramic manufacture, synthetic fertilizer production, cement clinker milling and concrete mixing [32].

\section{Significance of establishment of the international association for palm by-products}

One of the main objectives of By-Palms conference is to establish the first of its kind in the world the International Association For Palm By-Products as a measure to guarantee the continuation of endeavors to support the use of palm by-products on the international level for the realization of sustainable development. This association will be a forum for all parties, interested and involved in the use of palm by-product in so diverse fields as: fibers for the reinforcement of polymer composites, pulp and paper manufacture, wood substitutes, fodder, biochar, compost, pharmaceutical products and food, etc. It is expected that this association will serve as a meeting area of researchers, industrialists, palm owners, as well as marketing agencies. The roles of this association could be summarized as follows.

1. Propagation of the culture of utilization of the palm by-products (e.g. issuing and circulation of brochures of products, success stories and demonstration material, etc.)

2. Support and coordination of R \& D activities, associated with the palm by-products utilization in different applications.

3. Exchange and dissemination of knowledge, research results and experience, associated with the utilization of palm by-products for sustainable development.

4. Support of pilot projects, associated with the utilization of palm by-products (e.g. financial support, marketing support, etc.).

5. Participation in international conferences as well as holding of seminars, workshops, exhibitions and conferences on the utilization of palm by-products for sustainable development.

\section{References}

$$
\begin{aligned}
& \text { [1] حامد إبر اهيم الموصلي، التكنولوجيا والنمط الحضارى، دراسة حالة من العريش، مركز بحوث الثرق الأوسط، جامعة }
\end{aligned}
$$

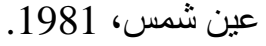

$$
\begin{aligned}
& \text { [2] حامد إبراهيم الموصلي، مشروع بحث استخدام جريد النخيل كخامة صناعية، التقرير الأول، مشروع قامت به كلية }
\end{aligned}
$$

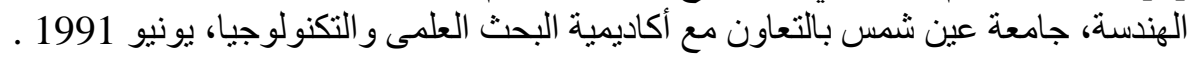

$$
\begin{aligned}
& \text { [3] حامد إبر اهيم الموصلي، تجارب استطلاعية قام بها مركز تتمية الصناعات الصغيرة، } 1996 .
\end{aligned}
$$




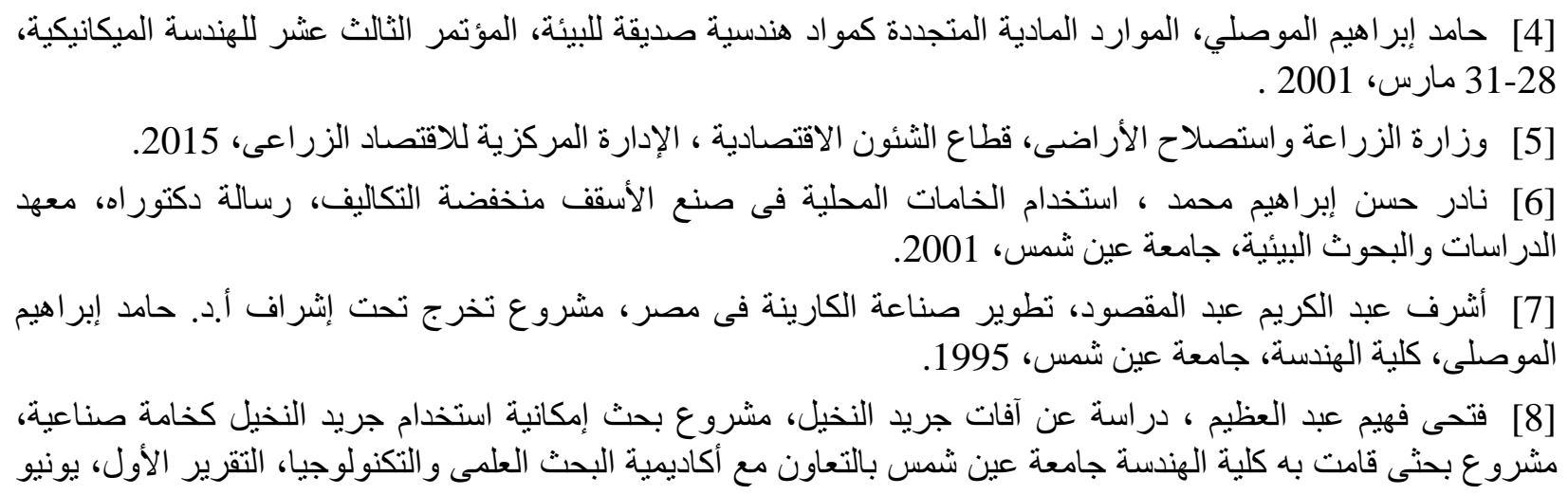

[9] M.H. Abd-Alla, Production of Acetone-Butanol-Ethanol from Spoilage Date Palm (Phoenix dactylitera L.) Fruits by Mixed Culture of Clostridium acetobutylicum and Bacillus subtilis, Biomass and Bioenenergy 42 (2012) 172-178.

https://doi.org/10.1016/j.biombioe.2012.03.006

[10] M.M.A. Abdel Samie, Study of the Potentiality of Use of the Palm Midrib in Charcoal Production: A master thesis, the Faculty of Engineering, Ain Shams University, Cairo, 2018.

[11] A. Acourene, A. Ammouche, Optimization of Ethanol, Citric Acid and $\alpha$-Amylase Production from Date Wastes by Strains of Saccharomyces cerevisiae, Aspergillus Niger and Candida Guilliermondii, Fermentation, Cell Culture and Bioengineering 39 (2012) 759-766. https://doi.org/10.1007/s10295-011-1070-0

[12] M.M. Ahmed, Palm Secondary Products as a Source of Organic Material for Compost Production: Applied Examples from Egypt. The First International Conference on Use of Palm By-Products for Sustainable Development, 15-17 Dec., 2018 (accepted as an oral presentation).

[13] F.M. Al-Oqla and others, Combined Multi-criteria Evaluation Stage Technique as an Agro Waste Evaluation Indicator for Polymeric Composites: Date Palm Fibers as a Case Study, Bio Resources 9-3 (2014) 4608-4621.

[14] D.R. Bogati, Cellulose Based Biochemicals and Their Applications Saiman University of Applied Sciences, Faculty of Technology: Bachelor's Thesis, 2011.

[15] Brain MLEOD, Panel Source International, Dawn in the grain forest. Proceedings of the meeting of the Eastern Canadian Section of the Forest Products Society, Winnipeg, Manitoba, (1999)19-20.

[16] Central Agency for Mobilization and Statistics, USDA; Foreign Agriculture Service, Global Agriculture Information Network, Egypt, Wood Sector Report, 29/9/2015.

[17] M. Chandrasekaran, A.H. Bahkali, Valorization of Date Palm (Phoenix dactylitera) Fruit Processing By-products and Wastes Using Bioprocess Technology-Review, Saudi Journal of Biological Sciences, King Saud University, 2012.

[18] Crops for Sustainable Enterprise, Design for Sustainable Development. European Foundation for the Improvement of Living and Working Conditions, Wyattville Read, Longhlinstown Co., Duplin, Ireland, 2000. 
[19] A. Dehghani and others, Mechanical and Thermal Properties of Date Palm Leaf Fiber Reinforced Recycled Poly (ethylene terephthalate) Composites, Materials and Design, EL SEVIER, 2013.

[20] K.M. Elerian and others. Investigation on the Use of Cellulose-Based Nano Fibers for Polymer Composites Reinforcement. El Azhar University Journal, 2015.

[21] M.S. El-Kinawy, Treatments of Palm Midrib to Improve the Mechanical Properties Compared to Imported Woods. A Ph.D. thesis, the Faculty of Engineering, Ain Shams University, Cairo, 2006.

[22] H.I. El-Mously, M.S. Saber, Medium Density Fiberboards from the Date Palm Residues: A Strategic Industry in the Arab World. The First International Conference on the Palm ByProducts, Aswan, Egypt, 15-17 Dec. 2018.

[23] H.I. El-Mously, Date Palm Midrib Utilization Project. A research project conducted by the Centre for Development of Small-Scale Industries, the Faculty of Engineering, Ain Shams University in Collaboration with IDRC, First technical report, 1994.

[24] H.I. El-Mously, Date Palm Utilization Project. Final report. A project conducted by the Centre for Development of Small-Scale Industries, Fac. Of Engineering, Ain Shams Univ. in collaboration with IDRC, Cairo, Oct., 1995.

[25] H.I. El-Mously, Innovating Green Products as a Mean to Alleviate Poverty in Upper Egypt. 1st International Joint Symposium on "Product Development and Innovation, Ain Shams University 3-5 May 2016.

[26] H.I. El-Mously, Project of Care of Palms in El-Bahariah Oases, A project conducted by the Faculty of Engineering, Ain Shams University in collaboration, with the Ministry of Environment, Final Report, Cairo, 2016.

[27] H.I. El-Mously, Resources Searching for a Management, The Expert Consultation on Date Palm Residues Utilization. FAO Regional Office, Cairo, 27-29 Oct., 1997.

[28] A.B. El Shabasy, H.I. El Mously, Study of the Variation of Tensile Strength Across the Cross Section of Date Palm Leaves' Midrib. Proceedings of the 5th European Conference on Advanced Materials and Processes and Applications, Maastricht, the Netherlands, 21-23 April, 1997.

[29] T.M. El Sherbeny, Use of Palm Midribs as Structural Elements, A master thesis. Institute of Environmental Studies, Ain Shams University, Cairo, 2010.

[30] A.A. El-Tahan and others. Upgrading Palm Fronds Through Different Treatments to be Used as Animal Feed. Egyptian J. Nutrition and Feeds 16-2 (2013) 235-242.

[31] EU Timber Regulation 2013, European Commission.

[32] J.M. Harkin, Lignin and its Uses, U.S. Department of Agriculture, Forest Service, Forest Products Laboratory, Madison, WIS., 1969.

[33] L. Helen, J. Gertsakis. Design \& Environment. Greenleaf Publishing, 2001.

[34] S.A. Ibrahim and others. Effect of Using Date Palm Waste on Performance, Carcass Characteristics and Economic Efficiency of Gemaza Growing Chicks. Egyptian J. Nutrition and Feeds 16-2 (2013 309-318. 
[35] R. Khiari and others. Tunisian Date Palm Rachis Used as an Alternative Source of Fibers for Papermaking Applications, Bio Resources 6-1 (2011) 265-281.

[36] P. Khristova and other. Alkaline Pulping with Additives of Date Palm Rachis and Leaves from Sudan, Bioresource Technology 96 (2005) 79-85.

https://doi.org/10.1016/j.biortech.2003.05.005

[37] M.S.A. Kinawy, Study of the Appropriate Conditions of the Press-Cycle for the Manufacture of Palm Midrib-Core Blockboards. A master thesis, the Faculty of Engineering, Ain Shams University, 1997.

[38] R. Maylor, Pioneering the Production of Oil Palm MDF. Dyno Resin Technology 1 (1999).

[39] M.M. Megahed, Hamed El-Mously, Anatomical Structure of Date Palm Leaves' Midrib and its Variation Across and Along the Midrib, IUFRO XX World Congress, Tampere, Finland, 1995.

[40] V. Menon and others. Value added Products form Hemicellulose: Bio technological Perspective, Division of Biochemical Sciences, National Chemical Laboratory, India.

[41] Y.m. Monsour and Others, Utilizing Palm Rachis for Eco-friendly and Flexible Construction in Egypt (C) SBE-Cairo, 2016.

[42] R.A. Naser and others. Measurement of Some Properties of Pulp and Paper Made from Date Palm Midribs and Wheat Straw by Soda-AQ Pulping Process. Measurement 62 (2015) 179180. https://doi.org/10.1016/j.measurement.2014.10.051

[43] E. Omrani and others. State of Art on Tribdogical Behavior of Polymer Metric Composites Reinforced with Natural Fibers in the Green Materials World. Engineering Science and Technology, an International Journal, 2015.

[44] Proceedings of the Meeting of the Eastern Canadian Section on the Forest Products Society, Winnipeg, Manitova, Canada, May 1999.

[45] L. Ramacho. Sustainable Consumption Provides Opportunities for Developing Countries. Industry and Environment, UNEP, 22-4 (1999).

[46] A.M. Tayssier, An Investigation into the Conditions of Manufacture of Lumber-Like Blocks from Date Palm Leaves' Midribs: A master thesis, the Faculty of Engineering, Ain Shams University, 1996.

[47] G. Tsoumis, Science and Technology of Wood. Van Nostrand Reinhold, New York, 1991.

[48] A.A. Waszzan, The Effect of Surface Treatment on the Strength and Adhesion Characteristics of Phoenix dactylifera L. (Date Palm) Fibers, International Journal of Polymeric Materials, 55 (2006) 485-499. https://doi.org/10.1080/009140391001804

[49] J.A. Youngquist and others. Agricultural Fibers in Composition Panels. 1303 on: Thomas M.,ed. Proceedings of the 27th International Particleboard Composite Materials Symposium, Pullmann, 30-31 March, 1993, Washington State University, 1993.

[50] Zaid Ab delouahhab, Date Palm Cultivation. Date Production Support Programme in Namibia, FAO, Rome, 1999. 
APPENDIX (1)

A Summary of the Report of

Munich Institute for Wood Research

On

Palm Midrib Blockboards

Produced in El-Kharga Factory,

The New Valley Governorate 


\section{Institut für Holzforschung der Universität München 80797 München, Winzererstraße 45 Institutsleiter Prof.Dr.Dr.habil. G.Wegener Telefon (089) 306309 0; FAX (089) 30630911}

\section{Bewertung von "Date Palm Leaves' Midribs Blockboard" nach deutschen Sperrholznormen}

Gutachtliche Stellungnahme

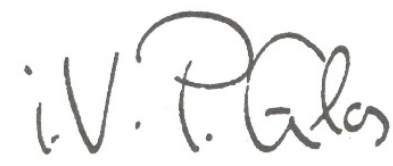

Institutsleiter Prof. Dr. G. Wegener

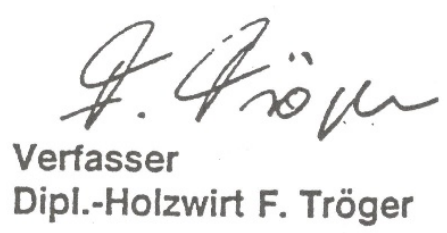




\title{
Quality Assessment of Palm Leaves' Midrib Blockboard According to German Standards
}

\author{
Fritz Tröger, Institute for Wood Research, Munich University
}

\author{
Summary
}

Early in 1996, the Institute for Wood Research of the University of Munich was commissioned by the GTZ office in Cairo to assess the quality of blockboard, developed as part of the GTZ project program, in orientation tests using German standards.

The institute's assessment report, in its introductory section, gives a description of the crosssectional structure of blockboard as defined in German standards. Blockboard is considered a high-quality, very well reputed wood based panel material. For cost reasons alone, applications are restricted to fields with above average quality specifications, e.g. in high-quality interior decorating (wall and ceiling panels), high-quality furniture and equipment manufacture.

Six blockboard samples measuring $1,000 \mathrm{~mm} \times 500 \mathrm{~mm} \times 13 \mathrm{~mm}$ constituted the test material supplied by the Egyptian plant El-Kharga. "Date Palm Leaves' Midribs Blockboard", as this panel with a centre layer of palm leaves' midribs is officially called, has a cross-sectional structure according to the principles of cross-banded lumber veneered board. The block core consists of slats cut from palm leaves' midribs, with a cross section of $10 \mathrm{~mm} \times 10 \mathrm{~mm}$. Surface veneers from poplar wood, $1.5 \mathrm{~mm}$ thick, are glued onto both sides of the block core using urea formaldehyde resin.

Tests involved the investigation of the following material properties: Moisture content (DIN 52 375), thickness swelling (DIN 52 364), density (DIN 53 374), internal bond strength (DIN 53 255), bending strength (DIN 52 371) and specifications regarding surface veneer and core layer (DIN 68 705, part 2).

Overall, the investigation of the material properties of Date Palm Leaves' Midribs Blockboard led to consistently positive results. Special attention is drawn to the following board characteristics:

1. The surfaces of the poplar wood veneers were evaluated class 1 and class 2 on top and underneath respectively. Some veneer surfaces proved excessively rough. This should be brought to the attention of the supplier.

2. The core of the blockboard is the centre layer which consists of slats made of the midribs of palm leaves. Emphasis is placed on the fact that this centre layer of palm leaves midribs fulfilled most specifications for centre layers made from wood. In future care should be taken to cut palm leaves' midribs in such a manner that slats with angles of $90^{\circ}$ are achieved as well as being full edged. Grading for first and second choice could be considered.

3. The results of the internal bond test covid not be better. The leverage-break tests gave excellent results regarding the gluing of surface veneers and core layer (No. 1 ranking according to DIN 53255 ). 
4. For surface veneers with the grain oriented in parallel to the longitudinal axis of the specimens bending strength was in the range of 37 to $43 \mathrm{~N} / \mathrm{mm}^{2}$. As expected, the bending strength range for veneers with grain perpendicular to the longitudinal axis of specimens was, at 27 to $30 \mathrm{~N} / \mathrm{mm}^{2}$, considerably lower.

In summarizing the results, it can be confirmed that Palm Leaves' Midrib Blockboard can be considered a valuable wood-based materials panel. On account of its good mechanical properties this panel is suitable for a great number of applications such as furniture manufacture, interior fitting, container and equipment manufacture as well as wall and ceiling panelling. 


\title{
APPENDIX (2)
}

\author{
A Certificate from the UNICEF Concerning \\ The Project of Utilization of Palm Midrib \\ Blockboards in the Manufacture of \\ Community Schools Furniture in Asiut, Sohag \\ And Kena Governorates \\ In 1995
}




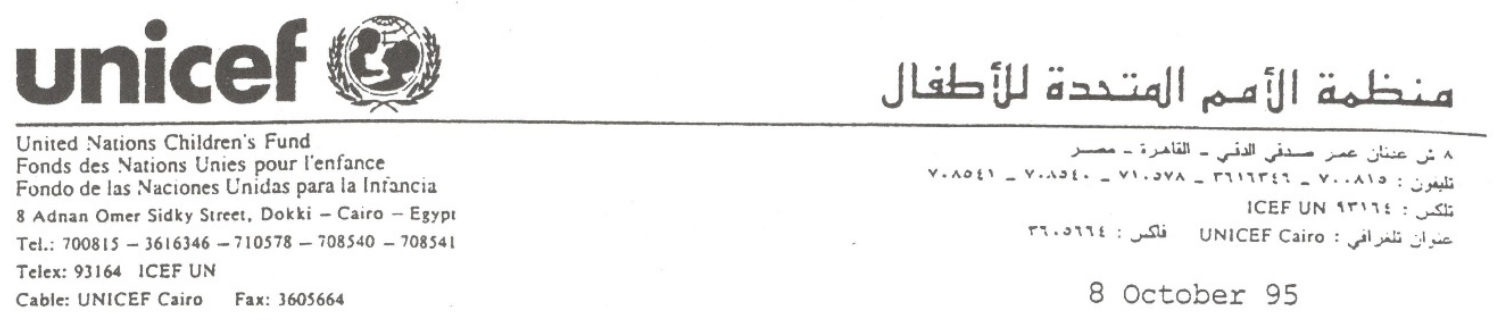

To Whom It May Concern

This is to certify that the cooperative agreement for the production of Date palm mid rib block board between UNICEF and The Center For Development Of Small Scale Industries, Faculty of Engineering - Ain Shams University and the Governorate of the New Valley was satisfactorily completed. The production was of good quality and delivered on time.

UNICEF has been very happy to support this initiative as it is in line with the development of appropriate local technology. Moreover this type of production is environmentally friendly and contributes to the creation of employment opportunities at the local level.
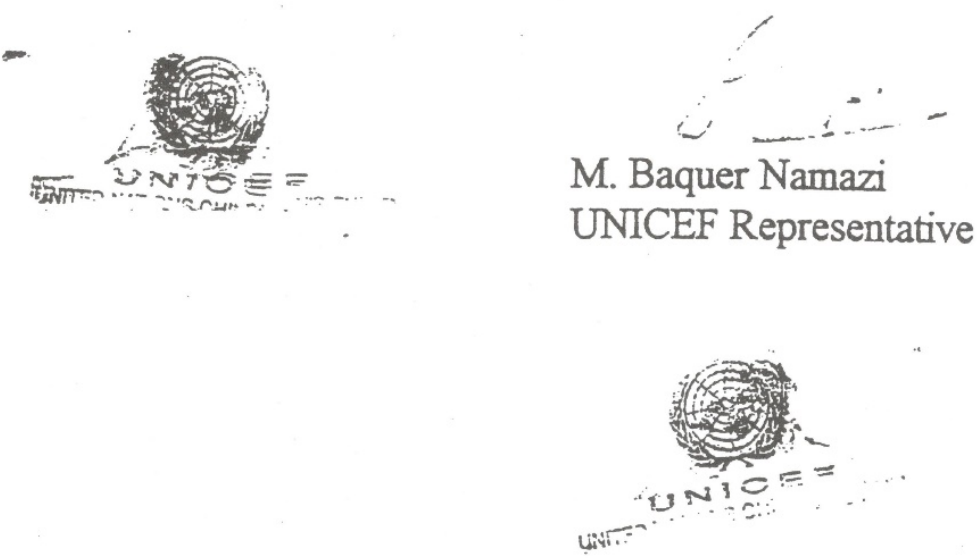


\title{
APPENDIX (3)
}

\author{
A Copy of the Certificate, \\ Obtained from Euromat-97 Conference \\ On the Research, titled: \\ A New Lumber-like Product \\ From Date Palm Leaves' Midribs
}


Bond voor Materialenkemnis

\section{CERTIFICATE HOUWINK - PRIZE}

The Board of the Netherlands Society for Materials Science (Bond voor Materialenkennis) decided to grant the HOUWINK-PRIZE 1997 to the best poster presented at EUROMAT 97.

A jury initiated by the Board consisting of Ir. M. Bliek, Ir. H. Toersen and Dr. A.P.M. van der Veek has nominated as winner:

\section{The Ain Shams University at Cairo, Egypt \\ Centre for Development of Small-scale Industries and Local Technologies}

for their poster:

"A New Lumber - like Product from Date Palm Leaves' Midribs" by: A.M. Taysseer, H.I. El-Mously and M.M. Megahed

The prize of EU 1000.00 was given to Prof. Dr. Hamed El-Mously at the closing session of the meeting.

Chairman of the Jury

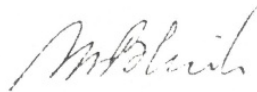

Ir. M. Bliek
Netherlands Society for Materials Science

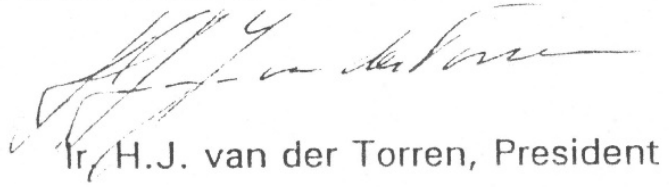

Postbus 390

3330 AJ Zwijndrecht
Tel. $078 \cdot 6192655$

Telefax $078 \cdot 6195735$

E-mail:bvm@worldonline.nl

Postbank: 209046

Bank: $A B N \cdot A M R O$ 


\title{
APPENDIX (4)
}

\author{
Results of testing of samples \\ Of MDF, made from the products \\ Of pruning of date palms, \\ Collected from El-Bahariah Oases
}




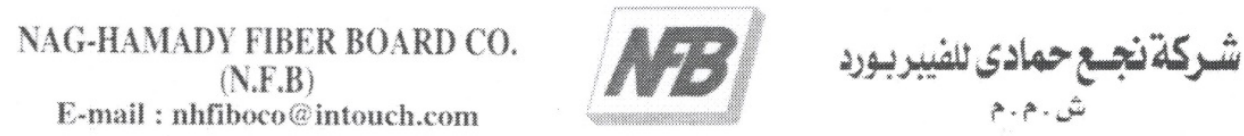

E-mail : nhfiboco@intouch.com

$$
\text { ?.?. A }
$$

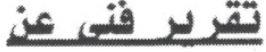

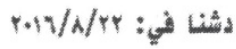

الاختبارات الفيزيائية والميكانيكية لعينات الاثواح العصنعة معليا من المنتجات

الثانوية لنثيل البلح

1- الاختبار ات الفيز باثية , الكيمياثية

\begin{tabular}{|c|c|c|c|c|c|c|}
\hline أنبعات الضر مانين & الامتصاص & التشرب & الترطو بة & الكثافية & السمك & الاختبار \\
\hline مجم/..1جم & $\%$ & $\%$ & $\%$ & سجم/par & م & الو حدة \\
\hline$r \gamma, 0 q$ & $\triangle A,+2$ & $17, \mathrm{~V}$ & $0, \%$ & vor,... & $1 \%, \cdot$. & النتيجة \\
\hline$\cdot, \mathrm{AV}$ & $Y, 0$ & 1,5 & .11 & $r \varepsilon, r A$ & $\cdot, \cdot 2$ & الانحر اف المعياري \\
\hline EN120 & BS1142 & EN317 & EN322 & $\mathrm{EN} 323$ & EN323 & الططريقة القياسية \\
\hline$r \cdot \geq$ & & 10 & $11-\xi$ & - & - & المواصفات القياسية \\
\hline
\end{tabular}

\begin{tabular}{|c|c|c|c|c|c|}
\hline & & & & \multicolumn{2}{|c|}{ 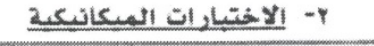 } \\
\hline $\begin{array}{l}\text { Surface } \\
\text { Sulandness } \\
\text { sound }\end{array}$ & المر أبطة الداخلية & $\begin{array}{l}\text { لمعرونة } \\
\text { MOE }\end{array}$ & ملمامل الكسر & السمك & الاخُتبار \\
\hline ثيوتن & نيوتن/ممج & نيوتن/مسمب & نيوتن/مهr & $\infty$ & الو حذة \\
\hline $1, r o$ & $\cdot 4$ & pal1 & $\mathrm{rt}, \mathrm{t}$. & ir & |النتيجة \\
\hline$\cdot, r$ & $\cdot, r$ & YA*, OY & $r, \pm 9$ & $\cdots, \cdot \xi$ & الانحر فض المعياز ي \\
\hline EN311 & EN319 & EN310 & EN310 & EN323 & المطريقة التقيأسية \\
\hline $1, r$ & $\cdot, 00$ & 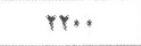 & $r \cdot, \cdot$. & & المواصفات الققياسية \\
\hline
\end{tabular}
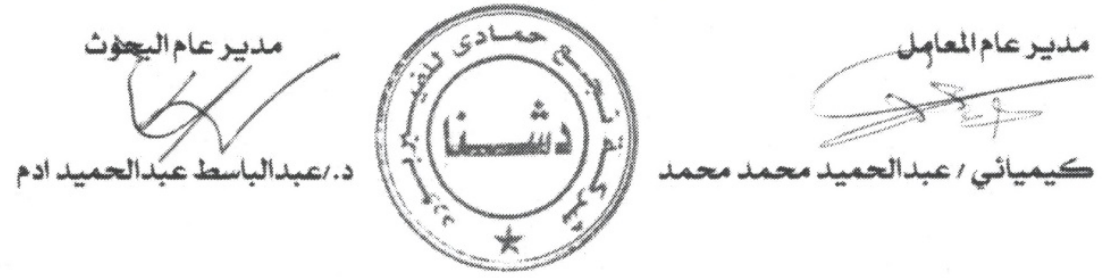

Cairo Office : 17 Gawad Hosni St., Cairo - Egypt

Tel: $+2 / 02 / 23922109+2 / 02 / 23902995$ Fax $:+2 / 02 / 23926511$

P.O.Box : 432 Mohamed Farid

Factory : Desna-Qena

Tels: $+2 / 096 / 6743281-+2 / 096 / 6743002 \mathrm{Fax}_{i}+2 / 096 / 6743003$

website : www.geocities.com/nhfiboco/company-profile html

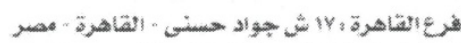

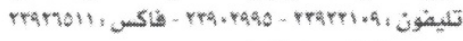

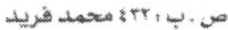

المصنيف: :

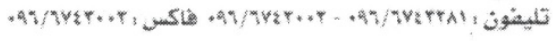

